\title{
Direct 3-Acylation of Indolizines by Carboxylic Acids for the Practical Synthesis of Red Light-Releasable Caged Carboxylic Acids
}

\author{
Kenji Watanabe ${ }^{a *}$, Nodoka Terao $^{a}$, Takashi Niwa ${ }^{a}$, and Takamitsu Hosoya ${ }^{a, b *}$ \\ ${ }^{a}$ Laboratory for Chemical Biology, RIKEN Center for Biosystems Dynamics Research (BDR), 6-7-3 Minatojima- \\ minamimachi, Chuo-ku, Kobe 650-0047, Japan \\ ${ }^{b}$ Laboratory of Chemical Bioscience, Institute of Biomaterials and Bioengineering, Tokyo Medical and Dental University \\ (TMDU), 2-3-10 Kanda-Surugadai, Chiyoda-ku, Tokyo 101-0062, Japan
}

\section{Contents}

1. Chemicals $\quad \mathrm{S} 2$

2. Optimization of conditions for synthesis of compounds $\mathbf{2}$ and $\mathbf{3}$ (Table S1) S3

3. Competition experiment between 2-methoxyindolizine (1) and benzyl alcohol (Figure S1) S4

4. Optimization of conditions for synthesis of compound 11 (Table S2) S5

5. Synthesis of compound 22 via acyl chloride (Figure S2) S6

$\begin{array}{ll}\text { 6. Kinetic studies (Figure } \mathbf{S 3} \text { and } \mathbf{S 4} \text { ) } & \text { S7-8 }\end{array}$

7. Photoreaction under hypoxia conditions (Figure S5) S9

8. NMR and HPLC charts $\quad$ S10-45

9. Chiral HPLC charts $\quad$ S46-47 


\section{Chemicals}

$N, N$-Dimethylformamide (DMF, deoxygenated), isopropyl alcohol ( $i$ - $\mathrm{PrOH}$, deoxygenated), dichloromethane $\left(\mathrm{CH}_{2} \mathrm{Cl}_{2}\right.$, deoxygenated), methanol $\left(\mathrm{CH}_{3} \mathrm{OH}\right.$, deoxygenated), ultrapure water, and 4-(4,6-dimethoxy-1,3,5triazin-2-yl)-4-methylmorpholinium chloride (DMT-MM) were purchased from FUJIFILM Wako Pure Chemical. Ethyl acetate (EtOAc), $n$-hexane, tert-butyl alcohol $(t-\mathrm{BuOH})$, dibromomethane $\left(\mathrm{CH}_{2} \mathrm{Br}_{2}\right)$, dimethyl sulfoxide (DMSO), acetonitrile $\left(\mathrm{CH}_{3} \mathrm{CN}\right.$, HPLC grade), thionyl chloride $\left(\mathrm{SOCl}_{2}\right)$, oxalyl chloride $\left((\mathrm{COCl})_{2}\right)$, $N, N$-diisopropylethylamine ( $i$ - $\left.\mathrm{Pr}_{2} \mathrm{NEt}\right)$, 4-dimethylaminopyridine (DMAP), disodium phosphate $\left(\mathrm{Na}_{2} \mathrm{HPO}_{4}\right)$, sodium dihydrogenphosphate $\left(\mathrm{NaH}_{2} \mathrm{PO}_{4}\right)$, cholic acid, sodium carbonate $\left(\mathrm{Na}_{2} \mathrm{CO}_{3}\right)$, cesium hydroxide monohydrate $\left(\mathrm{CsOH} \cdot \mathrm{H}_{2} \mathrm{O}\right)$, sodium sulfate $\left(\mathrm{Na}_{2} \mathrm{SO}_{4}\right)$, phosphoric acid $\left(\mathrm{H}_{3} \mathrm{PO}_{4}\right)$, copper(II) sulfate pentahydrate $\left(\mathrm{CuSO}_{4} \cdot 5 \mathrm{H}_{2} \mathrm{O}\right)$, sodium L-ascorbate, 1-naphthol, trifluoroacetic acid, and formic $\left(\mathrm{HCO}_{2} \mathrm{H}\right)$ acid were purchased from Nacalai Tesque. 1H-Benzotriazol-1-yloxytris(dimethylamino)phosphonium hexafluorophosphate (BOP), $N, N, N^{\prime}, N^{\prime}$-tetramethyl- $O$-( $N$-succinimidyl)uronium tetrafluoroborate (TSTU), 1 -

[bis(dimethylamino)methylene]-1H-benzotriazolium 3-oxide hexafluorophosphate (HBTU), 1[bis(dimethylamino)methylene]-1H-1,2,3-triazolo[4,5-b]pyridinium 3-oxide hexafluorophosphate (HATU); $O$-[(ethoxycarbonyl)cyanomethylenamino]- $N, N, N^{\prime}, N^{\prime}$-tetramethyluronium hexafluorophosphate (HOTU), 3H-1,2,3-triazolo[4,5-b]pyridin-3-ol (HOAt), ethyl cyano(hydroxyimino)acetate (oxyma), 4-methylbenzoic acid, 4-methoxybenzoic acid, 4-(methylthio)benzoic acid, 4-azidobenzoic acid, 4-chlorobenzoic acid, 4bromobenzoic acid, 4-cyanobenzoic acid, 2-methylbenzoic acid, (E)-2-methyl-3-phenylacrylic acid, 3methylbut-2-enoic acid, isonicotinic acid, (tert-butoxycarbonyl)-L-phenylalanine, benzoylglycylglycine, 2,2dimethyl-4-oxo-3,8,11,14,17-pentaoxa-5-azaicosan-20-oic acid, indomethacin, dimethyl sulfate, 3phenylpropionic acid, tris((1-benzyl-1H-1,2,3-triazol-4-yl)methyl)amine (TBTA), phenol (PhOH), benzyl alcohol $(\mathrm{BnOH})$, methylene blue, and benzoic acid were purchased from Tokyo Chemical Industry. 4(Hydroxymethyl)benzoic acid, 2-methyl-3-phenylpropanoic acid, zinc (II) acetate ( $\left.\mathrm{Zn}(\mathrm{OAc})_{2}\right)$, and serum albumin (human, A1653) were purchased from Merck. (tert-Butoxycarbonyl)-D-phenylalanine and succinylL-alanyl-L-prolyl-L-alanine $p$-nitroanilide (Suc-Ala-Pro-Ala- $p$ NA) were purchased from Peptide Institute. 1(3-Dimethylaminopropyl)-3-ethylcarbodiimide hydrochloride $(\mathrm{EDC} \cdot \mathrm{HCl})$ was purchased from Watanabe Chemical Industries. (1-Cyano-2-ethoxy-2-oxoethylidenaminooxy)dimethylaminomorpholinocarbenium hexafluorophosphate (COMU) was purchased from Oakwood Chemical. Pseudolaric acid B was purchased from PhytoLab. 17-Azido-3,6,9,12,15-pentaoxaheptadecan-1-amine was purchased from Broad Pharm. 1Hydroxybenzotriazole (HOBt) was purchased from Dojindo Laboratories. All purchased reagents were used as received. 


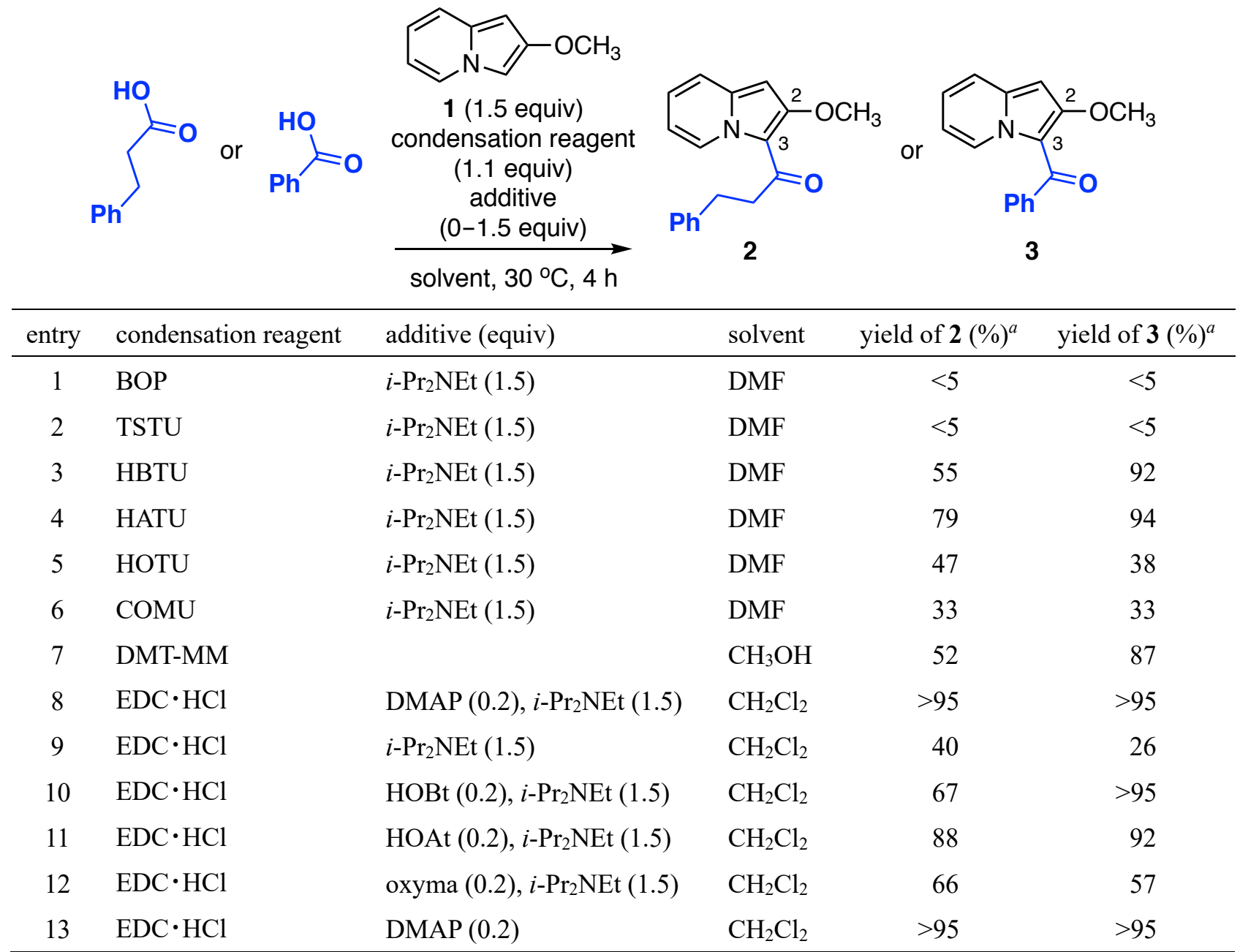

${ }^{a}$ Yields based on ${ }^{1} \mathrm{H}$ NMR measurements.

\section{Procedure}

To a solution $\left(\mathrm{CH}_{2} \mathrm{Cl}_{2}\right.$, DMF or $\left.\mathrm{CH}_{3} \mathrm{OH}, 0.25 \mathrm{~mL}\right)$ of carboxylic acid (3-phenylpropanoic acid for 2, benzoic acid for 3, 4-(hydroxymethyl)benzoic acid for 11, $50 \mu \mathrm{mol}, 1$ equiv) and 2-methoxyindolizine (1, $11 \mathrm{mg}, 75$ $\mu \mathrm{mol}, 1.5$ equiv) in a $4 \mathrm{~mL}$ vial were added additives ( $0-1.5$ equiv), condensation reagent ( $55 \mu \mathrm{mol}, 1.1$ equiv) and a magnetic stir bar. The vial was filled with argon and the solution was stirred at $30{ }^{\circ} \mathrm{C}$ for $4-20 \mathrm{~h}$. After the reaction, the organic solvents were evaporated. A solution of $\mathrm{CH}_{2} \mathrm{Br}_{2}\left(3.5 \mu \mathrm{L}, 50 \mu \mathrm{mol}, 1\right.$ equiv) in $\mathrm{CDCl}_{3}$ $(1 \mathrm{~mL})$ was added to the residue. The solution was washed with brine $(2 \mathrm{~mL})$. The organic layer was dried with $\mathrm{Na}_{2} \mathrm{SO}_{4}$. The solution was transferred to an NMR tube, and ${ }^{1} \mathrm{H}$ NMR measurement was performed. The reaction yields (\%) were determined by comparison of the integral values of the peaks corresponding to the products and that of $\mathrm{CH}_{2} \mathrm{Br}_{2}$ as an internal standard. 


\section{Competition experiment between 2-methoxyindolizine (1) and benzyl alcohol (Figure S1)}

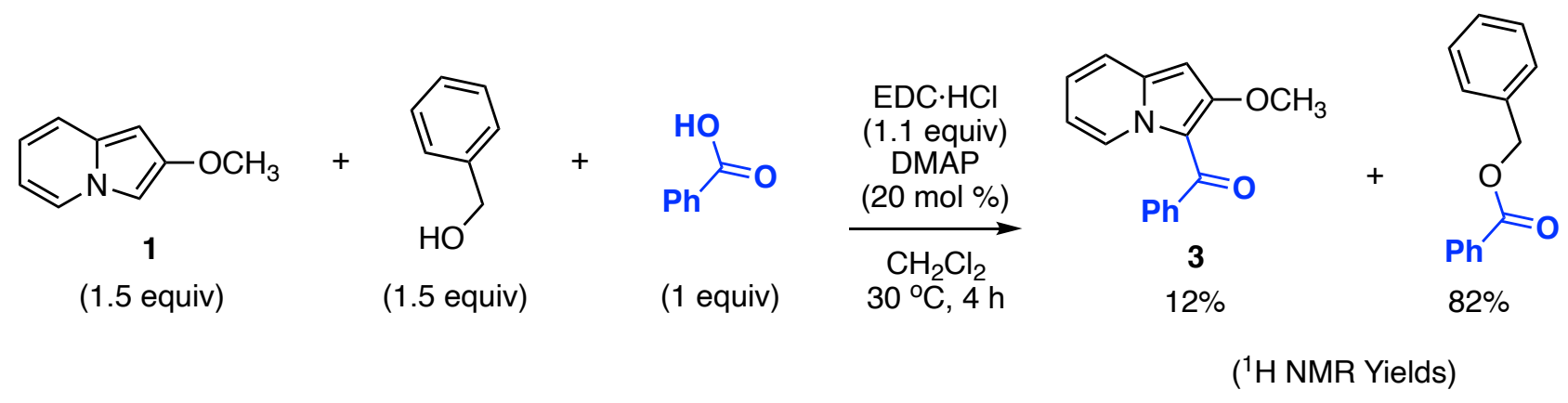

\section{Procedure}

To a solution $\left(\mathrm{CH}_{2} \mathrm{Cl}_{2}, 0.50 \mathrm{~mL}\right)$ of benzoic acid (12.2 mg, $99.9 \mu \mathrm{mol}, 1$ equiv), benzyl alcohol $(16.2 \mathrm{mg}, 0.150$ mmol, 1.5 equiv), 2-methoxyindolizine (1,22.1 $\mathrm{mg}, 0.150 \mathrm{mmol}, 1.5$ equiv), and 4-dimethylaminopyridine (DMAP, $1.22 \mathrm{mg}, 9.99 \mu \mathrm{mol}, 20 \mathrm{~mol} \%$ ) in a $4 \mathrm{~mL}$ vial were added $\mathrm{EDC} \cdot \mathrm{HCl}(21.1 \mathrm{mg}, 0.110 \mathrm{mmol}, 1.1$ equiv) and a magnetic stir bar. The vial was filled with argon and the solution was stirred at $30^{\circ} \mathrm{C}$ for $4 \mathrm{~h}$. After the reaction, the organic solvents were evaporated. A solution of $\mathrm{CH}_{2} \mathrm{Br}_{2}$ (7.02 $\mu \mathrm{L}, 0.100 \mathrm{mmol}, 1$ equiv) in $\mathrm{CDCl}_{3}(1 \mathrm{~mL})$ was added to the residue. The solution was washed with brine $(2 \mathrm{~mL})$. The organic layer was dried with $\mathrm{Na}_{2} \mathrm{SO}_{4}$. The solution was transferred to an NMR tube, and ${ }^{1} \mathrm{H}$ NMR measurement was performed. The reaction yields (\%) were determined by comparison of the integral values of the peaks corresponding to the products and that of $\mathrm{CH}_{2} \mathrm{Br}_{2}$ as an internal standard. 
4. Optimization of conditions for synthesis of compound 11 (Table S2)

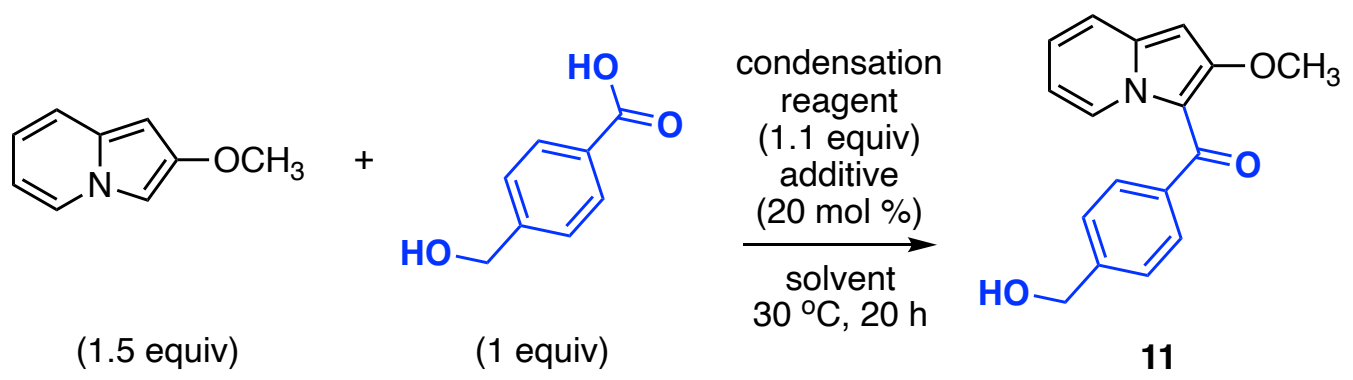

\begin{tabular}{clllc}
\hline entry & condensation reagent & additive & solvent & yield of 11 (\%) \\
\hline 1 & EDC $\cdot \mathrm{HCl}$ & DMAP & $\mathrm{DMF}$ & $5^{a}$ \\
2 & DMT-MM & & $\mathrm{DMF}$ & $17^{a}$ \\
3 & DMT-MM & & $\mathrm{CH}_{3} \mathrm{OH}$ & $77^{b}$ \\
\hline
\end{tabular}

${ }^{a}$ Yields based on ${ }^{1} \mathrm{H}$ NMR measurement. $\quad{ }^{b}$ Isolated yield.

\section{Procedure}

The experiments were performed according to the procedure of Table S1. 


\section{Synthesis of compound 22 via acyl halide (Figure S2)}

A)<smiles>O=C(O)N[C@@H](Cc1ccccc1)C(=O)O</smiles>

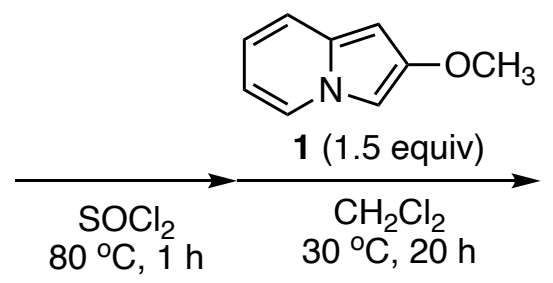<smiles>COc1cc2ccccn2c1C(=O)C(Cc1ccccc1)NC(=O)OCc1ccccc1</smiles>

22

not observed

B)<smiles>O=C(N[C@@H](Cc1ccccc1)C(=O)O)c1ccccc1</smiles><smiles>COc1cc2ccccn2c1</smiles><smiles>COc1cc2ccccn2c1C(=O)C(Cc1ccccc1)NC(=O)OCc1ccccc1</smiles>

22

not observed

\section{Procedure}

A) A solution of (tert-butoxycarbonyl)-L-phenylalanine (53.0 $\mathrm{mg}, 0.200 \mathrm{mmol}, 1$ equiv) and thionyl chloride $(1.0 \mathrm{~mL})$ was stirred at $80{ }^{\circ} \mathrm{C}$ for $1 \mathrm{~h}$ under argon atmosphere. After the reaction, thionyl chloride was evaporated. The residue was dissolved in $\mathrm{CH}_{2} \mathrm{Cl}_{2}(1.0 \mathrm{~mL}$ ), and 2-methoxyindolizine ( $44.2 \mathrm{mg}, 0.300 \mathrm{mmol}$, 1.5 equiv) was added. The solution was stirred at room temperature for $20 \mathrm{~h}$ under argon atmosphere. The reaction mixture was poured into EtOAc $(5 \mathrm{~mL})$ and brine $(5 \mathrm{~mL})$, and extracted with EtOAc $(5 \mathrm{~mL} \times 3)$. The combined organic layer was dried with $\mathrm{Na}_{2} \mathrm{SO}_{4}$ and evaporated. Formation of the product was not observed as judged from TLC analysis (standard sample: $R \mathrm{f}=0.60, n$-hexane:EtOAc $=2: 1$ ).

B) To a solution of (tert-butoxycarbonyl)-L-phenylalanine $\left(53.0 \mathrm{mg}, 0.200 \mathrm{mmol}, 1\right.$ equiv) in $\mathrm{CH}_{2} \mathrm{Cl}_{2}(1.0 \mathrm{~mL})$ were added oxalyl chloride (27.9 mg, $0.220 \mathrm{mmol}, 1.1$ equiv) and DMF (1.5 $\mu \mathrm{L}, 0.020 \mathrm{mmol}, 10 \mathrm{~mol} \%$ ) and a magnetic stirrer at $0{ }^{\circ} \mathrm{C}$. The solution was gradually warmed to room temperature and stirred for $4 \mathrm{~h}$. The solution was evaporated, and the residue was dissolved in $\mathrm{CH}_{2} \mathrm{Cl}_{2}(1.0 \mathrm{~mL})$. 2-Methoxyindolizine (44.2 $\mathrm{mg}$, $0.300 \mathrm{mmol}, 1.5$ equiv) was added to the solution. The solution was stirred at room temperature for $20 \mathrm{~h}$ under argon atmosphere. The reaction mixture was poured into EtOAc $(5 \mathrm{~mL})$ and brine $(5 \mathrm{~mL})$, and extracted with EtOAc $(5 \mathrm{~mL} \times 3)$. The combined organic layer was dried with $\mathrm{Na}_{2} \mathrm{SO}_{4}$ and evaporated. Formation of the product was not observed as judged from TLC analysis (standard sample: $R \mathrm{f}=0.60, n$-hexane:EtOAc $=2: 1$ ). 


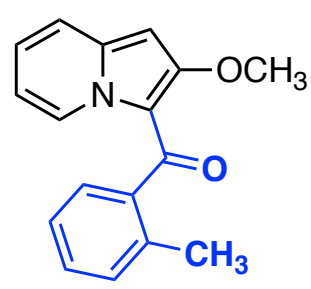

$15(2 \mathrm{mM})$

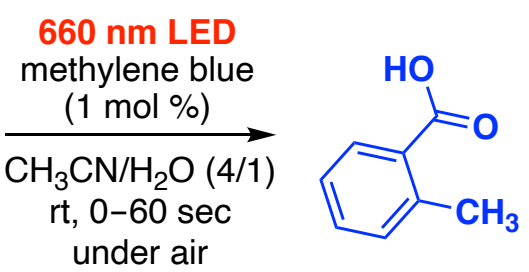

under air

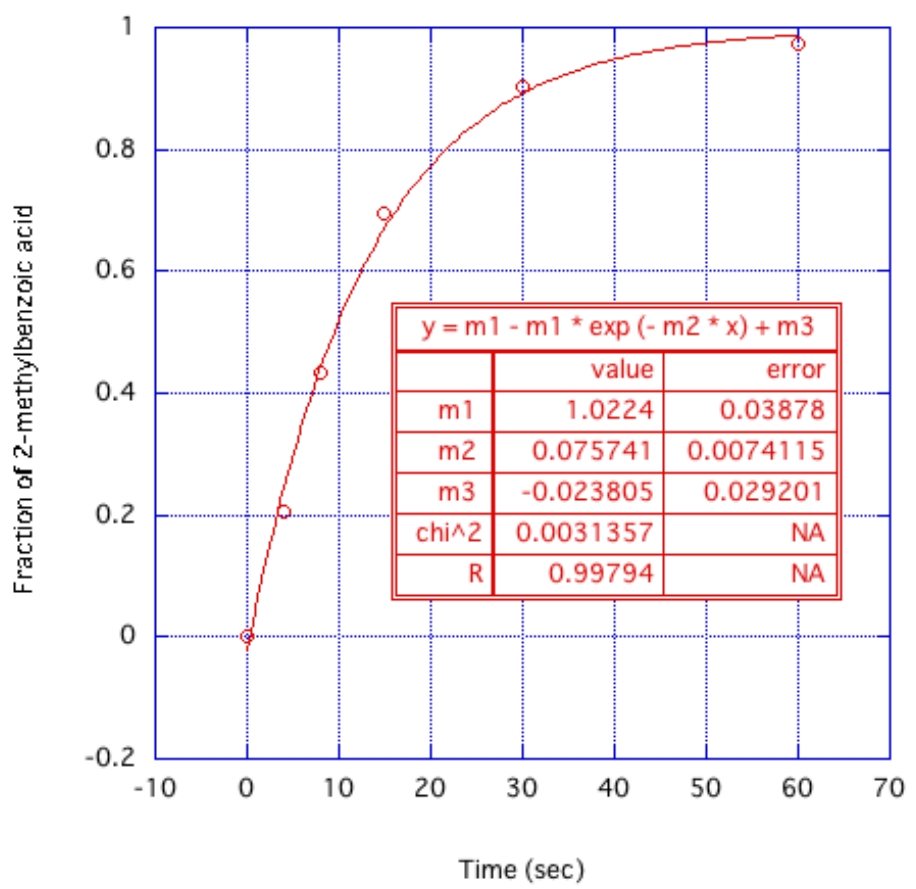

Figure S4. Representative result for time-dependent changes of the amount of 2-methylbenzoic acid released from compound 15 by photoirradiation. Conditions: $15(2.0 \mathrm{mM})$, methylene blue $(20 \mu \mathrm{M}, 1.0$ mol \%), $\mathrm{CH}_{3} \mathrm{CN} / \mathrm{H}_{2} \mathrm{O}(4 / 1,0.5 \mathrm{~mL}), 660 \mathrm{~nm}$ LED irradiation, rt, 0-60 sec. The amount of 2-methylbenzoic acid was measured by HPLC analysis. The curve fitting was performed by using pseudo first-order rate equation: $\mathrm{y}=\mathrm{m} 1-\mathrm{m} 1 * \exp (-\mathrm{m} 2 * \mathrm{x})+\mathrm{m} 3$, where $\mathrm{x}, \mathrm{y}, \mathrm{m} 1, \mathrm{~m} 2$, and $\mathrm{m} 3$ stand for time $(t)$, fraction of 2methylbenzoic acid at $t$, increase of fraction of 2-methylbenzoic acid from $t_{0}$ to $t_{\max }$, apparent rate constant $\left(k_{\mathrm{obs}}\right)$, and fraction of 2-methylbenzoic acid at $t_{0}$, respectively.

$k_{\text {obs }}\left(\mathrm{s}^{-1}\right)=0.0720 \pm 0.0027\left(0.0693\left(1^{\text {st }}\right), 0.0711\left(2^{\text {nd }}\right), 0.0757\left(3^{\text {rd }}\right)\right)$

\section{Procedure}

To a solution of 15 in acetonitrile $(2.5 \mathrm{mM}, 400 \mu \mathrm{L})$ in a $4 \mathrm{~mL}$ vial were added ultrapure water $(100 \mu \mathrm{L})$, an aqueous solution of methylene blue $(1.25 \mathrm{mM}, 8.0 \mu \mathrm{L}, 1.0 \mathrm{~mol} \%)$, and a magnetic stir bar under air. The solution was vigorously stirred by a magnetic stirrer at room temperature and photoirradiated for 0-60 sec. After the photoirradiation, a solution of 1-naphthol $(4.0 \mathrm{mM})$ in acetonitrile $(250 \mu \mathrm{L})$ was added, and a portion of the resulting solution was subjected to HPLC analysis. The reaction yields (\%) were determined by comparison of the peak area of 2-methylbenzoic acid and that of 1-naphthol as a standard. The peak areas of 2-methylbenzoic acid were calibrated against that of the standard (1-naphthol, $\mathrm{R}^{2}>0.99$ ). The conditions for HPLC analysis was as below: Column: Cosmosil MS-II C18, 5 $\mu \mathrm{m}, 4.6 \times 100 \mathrm{~mm}$ (Nacalai Tesque, Japan); Mobile phase: $\mathbf{A}=$ acetonitrile, $\mathbf{B}=$ aqueous $\mathrm{H}_{3} \mathrm{PO}_{4}(40 \mathrm{mM}), \mathbf{A} / \mathbf{B}=5 / 95$ to $95 / 5(0-30 \mathrm{~min})$. 


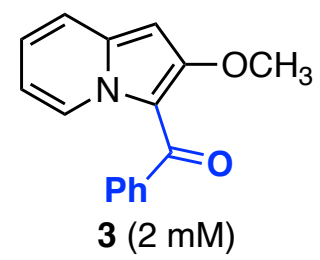

$660 \mathrm{~nm}$ LED

methylene blue
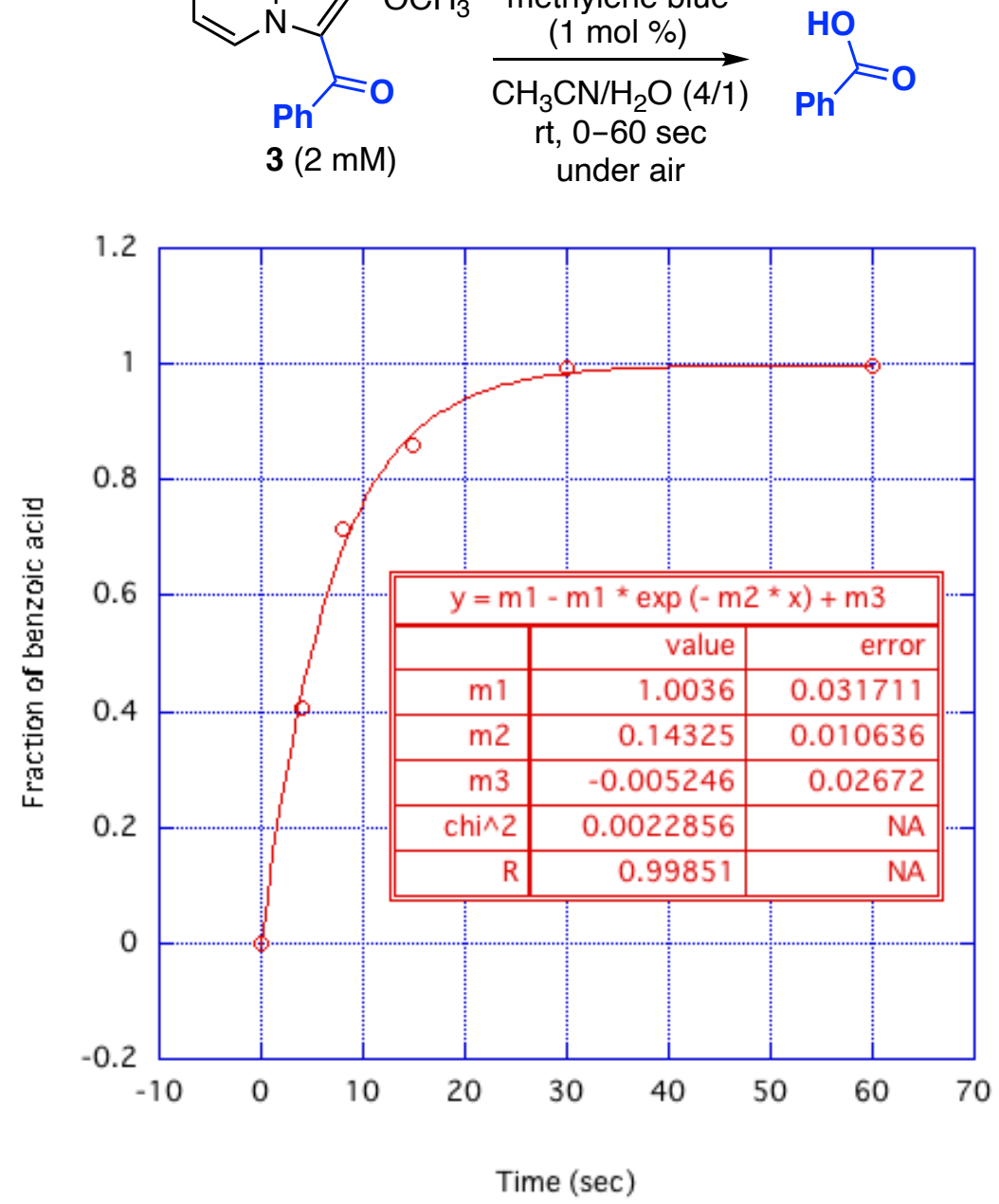

Figure S4. Representative result for time-dependent changes of the amount of benzoic acid released from compound 3 by photoirradiation. Conditions: $3(2.0 \mathrm{mM})$, methylene blue $(20 \mu \mathrm{M}, 1.0 \mathrm{~mol} \%), \mathrm{CH}_{3} \mathrm{CN} / \mathrm{H}_{2} \mathrm{O}$ (4/1, $0.5 \mathrm{~mL}), 660 \mathrm{~nm}$ LED irradiation, rt, 0-60 sec. The amount of benzoic acid was measured by HPLC analysis. The curve fitting was performed by using pseudo first-order rate equation: $\mathrm{y}=\mathrm{m} 1-\mathrm{m} 1 * \exp (-\mathrm{m} 2$ $* \mathrm{x})+\mathrm{m} 3$, where $\mathrm{x}, \mathrm{y}, \mathrm{m} 1, \mathrm{~m} 2$, and $\mathrm{m} 3$ stand for time $(t)$, fraction of benzoic acid at $t$, increase of fraction of benzoic acid from $t_{0}$ to $t_{\max }$, apparent rate constant $\left(k_{\mathrm{obs}}\right)$, and fraction of benzoic acid at $t_{0}$, respectively. $k_{\text {obs }}\left(\mathrm{s}^{-1}\right)=0.138 \pm 0.008\left(0.145\left(1^{\mathrm{st}}\right), 0.126\left(2^{\text {nd }}\right), 0.143\left(3^{\text {rd }}\right)\right)$

\section{Procedure}

The experiments were performed according to the procedure of Figure S3 except compound $\mathbf{3}$ and benzoic acid were used. 


\section{Photoreaction under hypoxia conditions (Figure S5)}

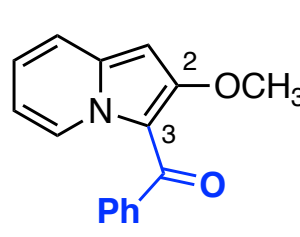

(2 mM)
$660 \mathrm{~nm}$ LED

methylene blue

$(1 \mathrm{~mol} \%)$

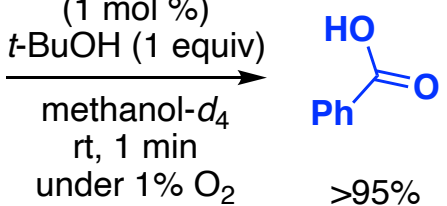

$\left({ }^{1} \mathrm{H}\right.$ NMR yield $)$

\section{Procedure}

A solution of 3 (2.0 mM, $5.0 \mathrm{~mL}, 1$ equiv) containiing tert-butyl alcohol (2.0 mM, 1.0 equiv), and methylene blue ( $20 \mu \mathrm{M}, 1.0 \mathrm{~mol} \%$ ) in methanol- $d_{4}$ was purged with $0.9947 \% \mathrm{O}_{2} /$ argon gas (Koatsu Gas Kogyo) for 20 min in a $20 \mathrm{~mL}$ vial equipped with a septum cap. A part of the solution $(700 \mu \mathrm{L})$ was transferred into a $4 \mathrm{~mL}$ vial filled with the gas and equipped with a septum cap and a magnetic stir bar via a gas tight syringe. The solution was vigorously stirred by a magnetic stirrer at room temperature and photoirradiated for $60 \mathrm{sec}$. After the irradiation, the solution was transferred to an NMR tube, and ${ }^{1} \mathrm{H}$ NMR measurement was performed. The reaction yield (\%) of benzoic acid was determined by comparison of the integral values of the peaks corresponding to benzoic acid and that of tert-butyl alcohol as an internal standard. 


\section{NMR and HPLC charts}

${ }^{1} \mathrm{H}$ NMR (400 MHz) and ${ }^{13} \mathrm{C}\left\{{ }^{1} \mathrm{H}\right\}$ NMR $(100 \mathrm{MHz})$ spectra of $2\left(\mathrm{CDCl}_{3}\right)$
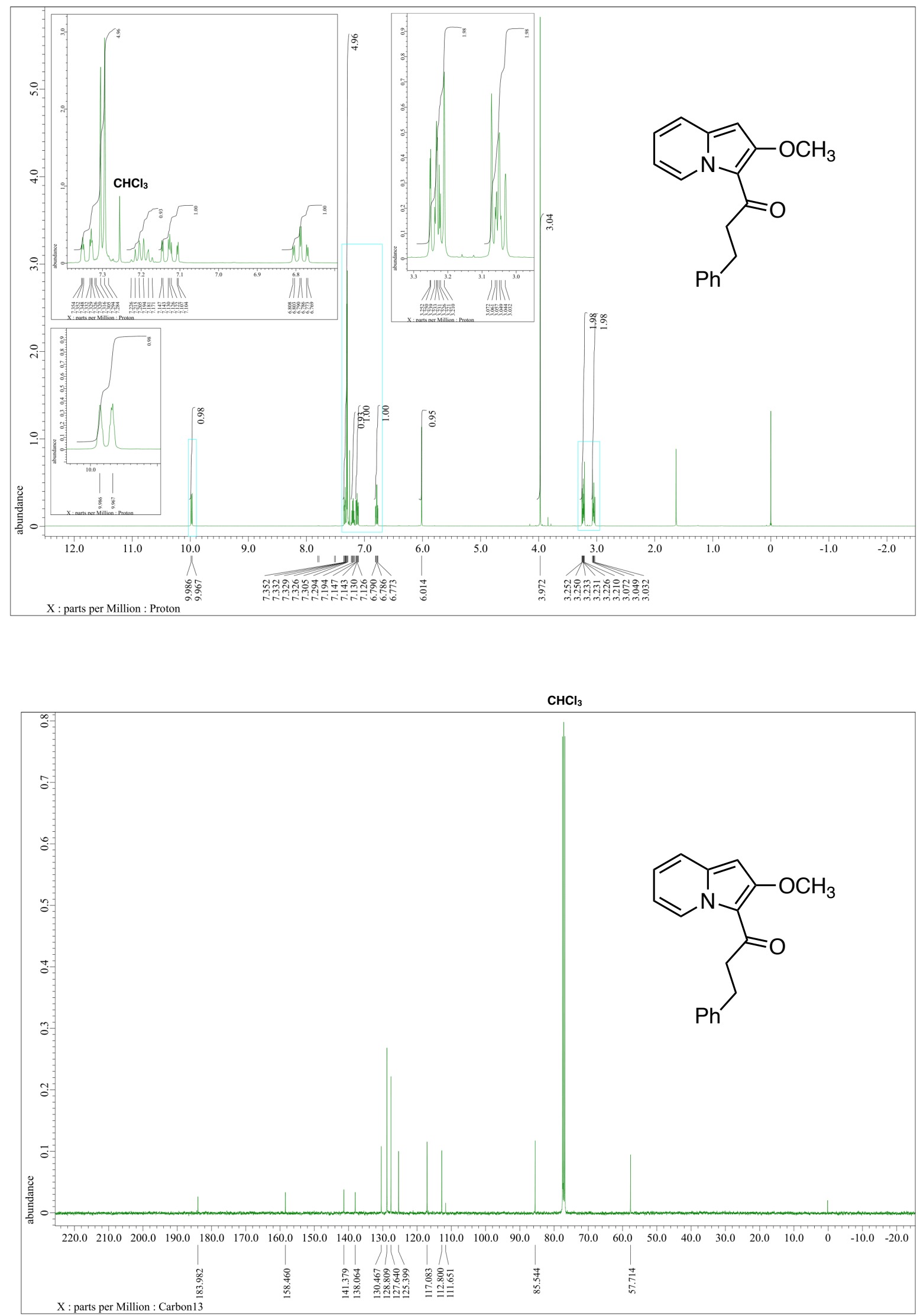
${ }^{1} \mathrm{H}$ NMR (400 MHz) and ${ }^{13} \mathrm{C}\left\{{ }^{1} \mathrm{H}\right\}$ NMR (100 MHz) spectra of $3\left(\mathrm{CDCl}_{3}\right)$
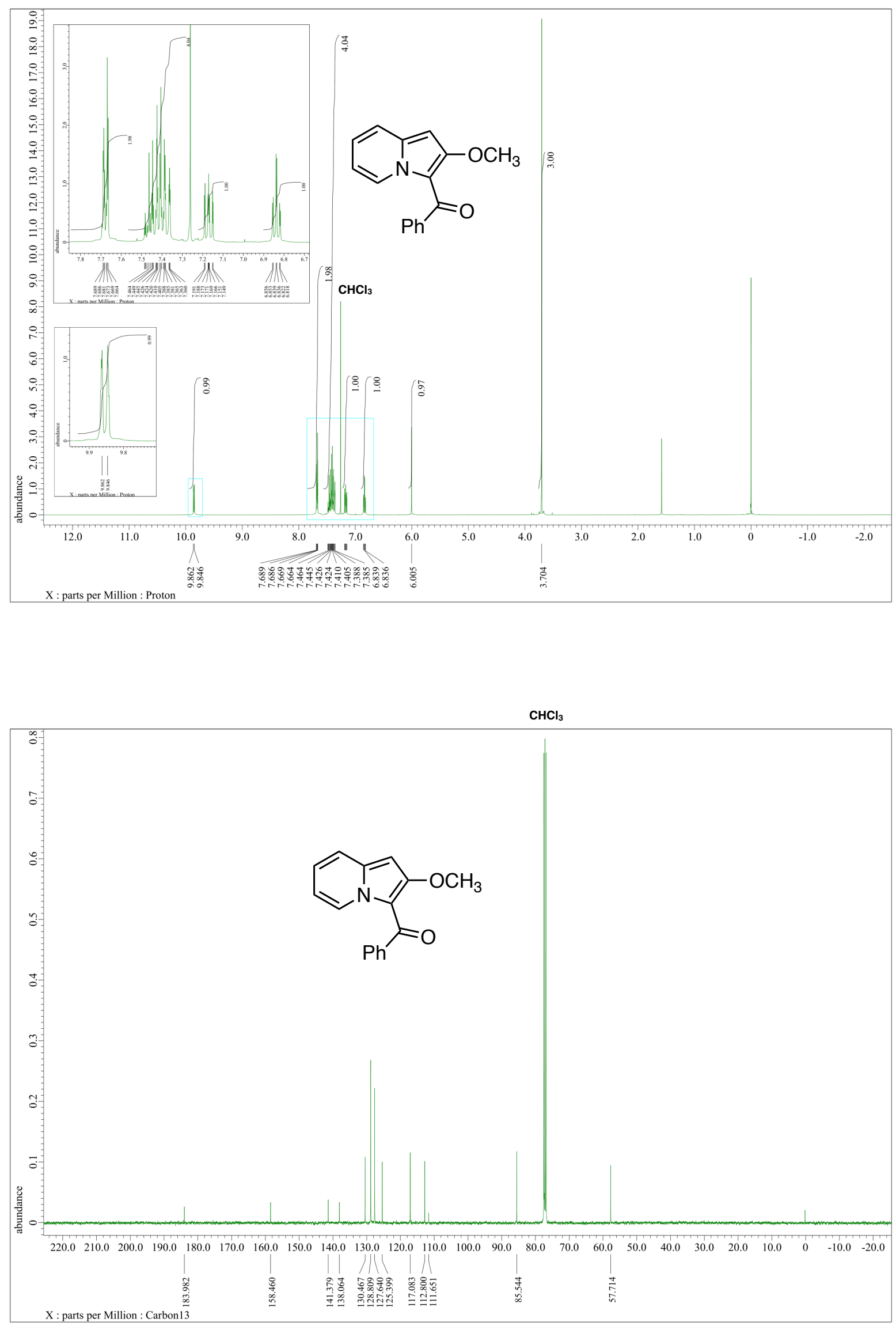
${ }^{1} \mathrm{H}$ NMR (400 MHz) and ${ }^{13} \mathrm{C}\left\{{ }^{1} \mathrm{H}\right\}$ NMR (100 MHz) spectra of $4\left(\mathrm{CDCl}_{3}\right)$
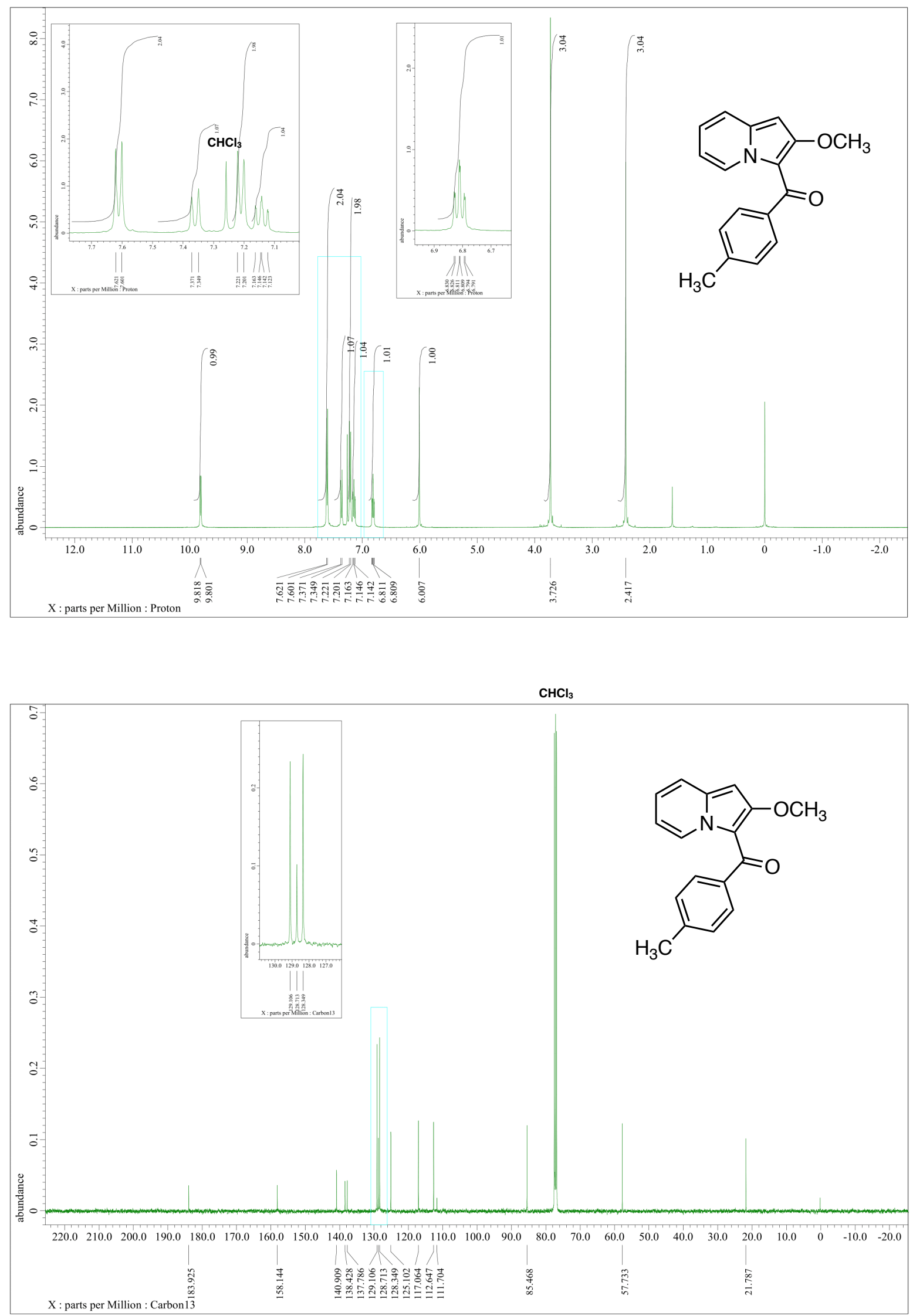
${ }^{1} \mathrm{H}$ NMR (400 MHz) and ${ }^{13} \mathrm{C}\left\{{ }^{1} \mathrm{H}\right\}$ NMR (100 MHz) spectra of $5\left(\mathrm{CDCl}_{3}\right)$
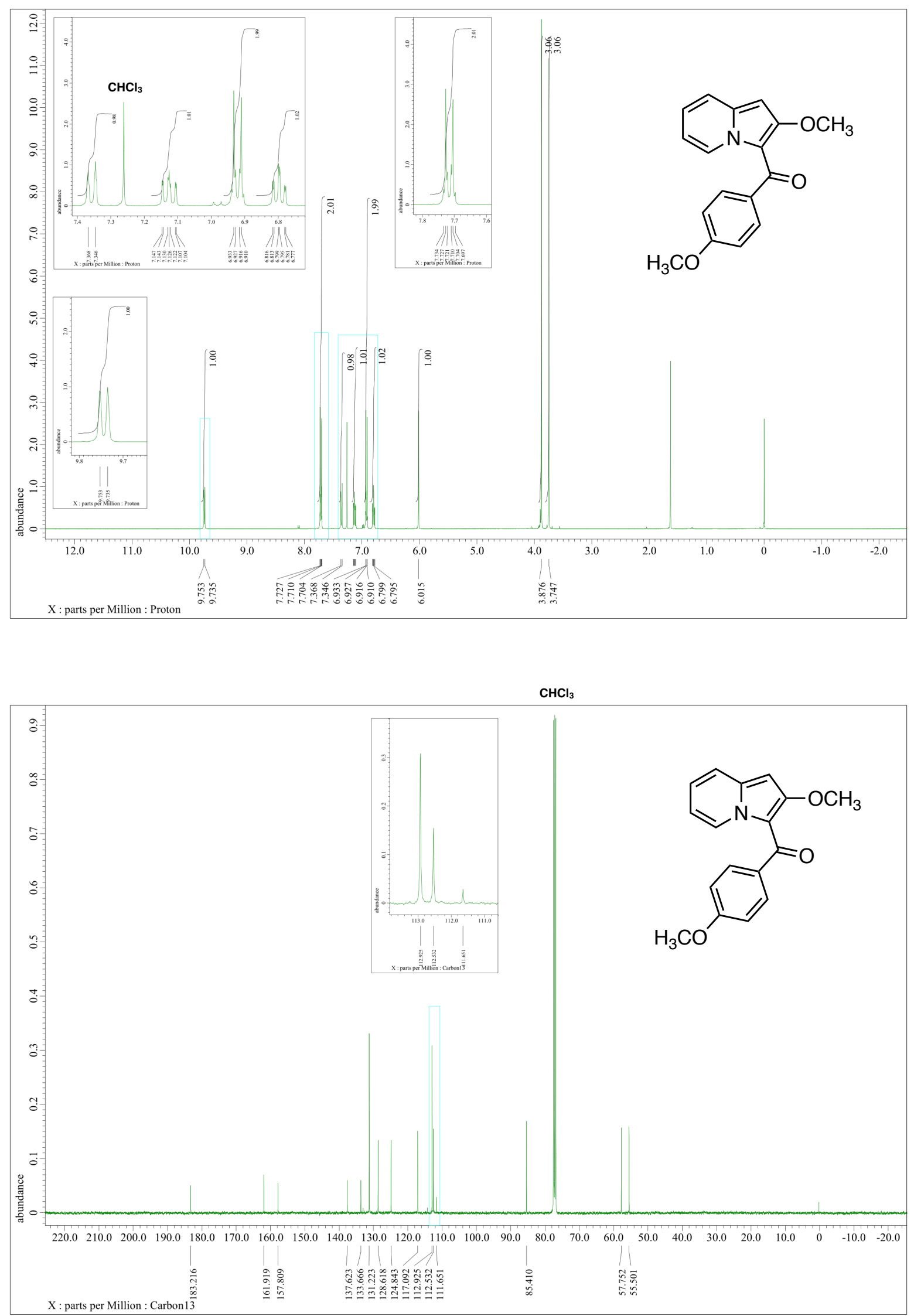
${ }^{1} \mathrm{H}$ NMR (400 MHz) and ${ }^{13} \mathrm{C}\left\{{ }^{1} \mathrm{H}\right\}$ NMR (100 MHz) spectra of $6\left(\mathrm{CDCl}_{3}\right)$
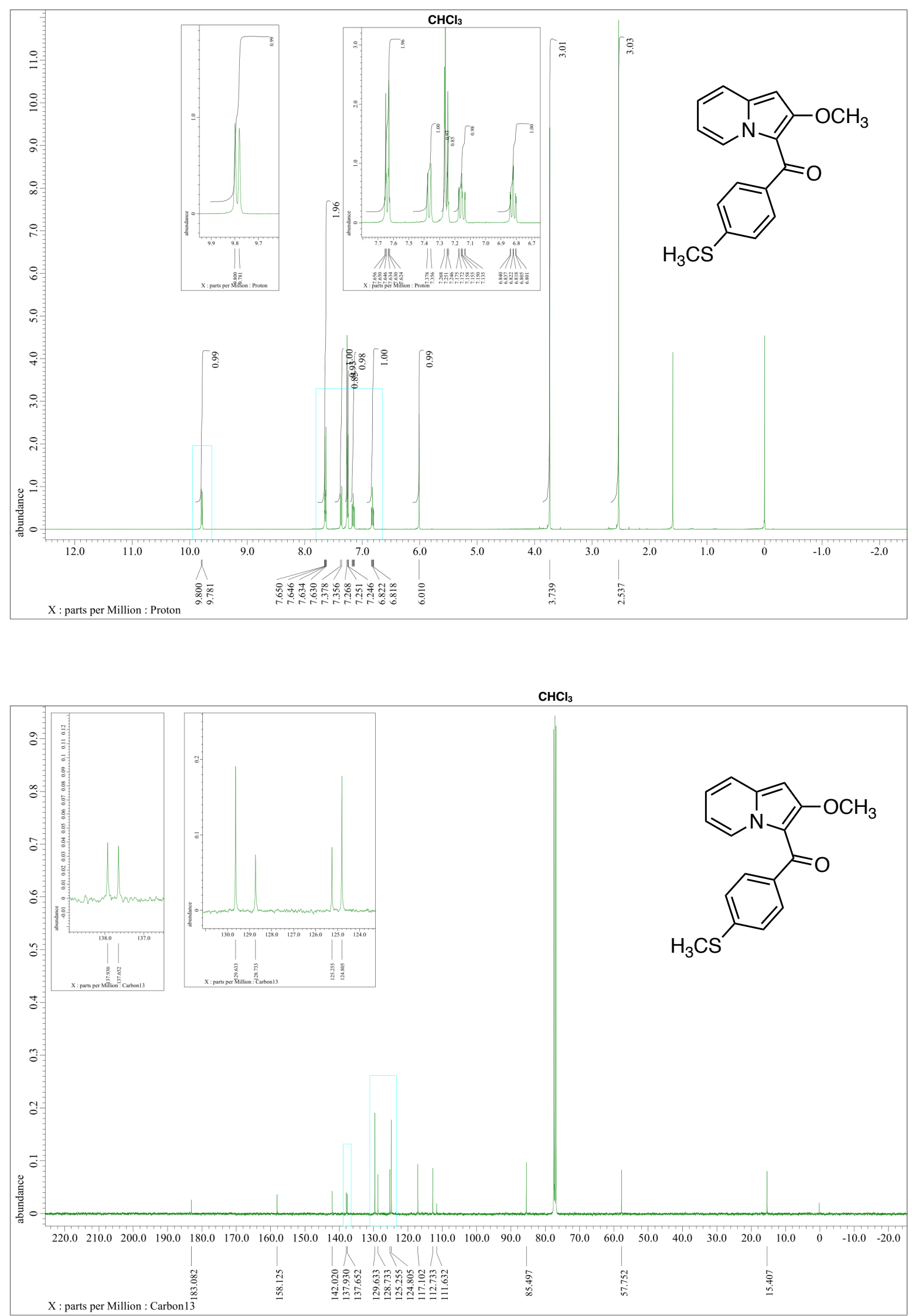
${ }^{1} \mathrm{H}$ NMR (400 MHz) and ${ }^{13} \mathrm{C}\left\{{ }^{1} \mathrm{H}\right\}$ NMR (100 MHz) spectra of $7\left(\mathrm{CDCl}_{3}\right)$
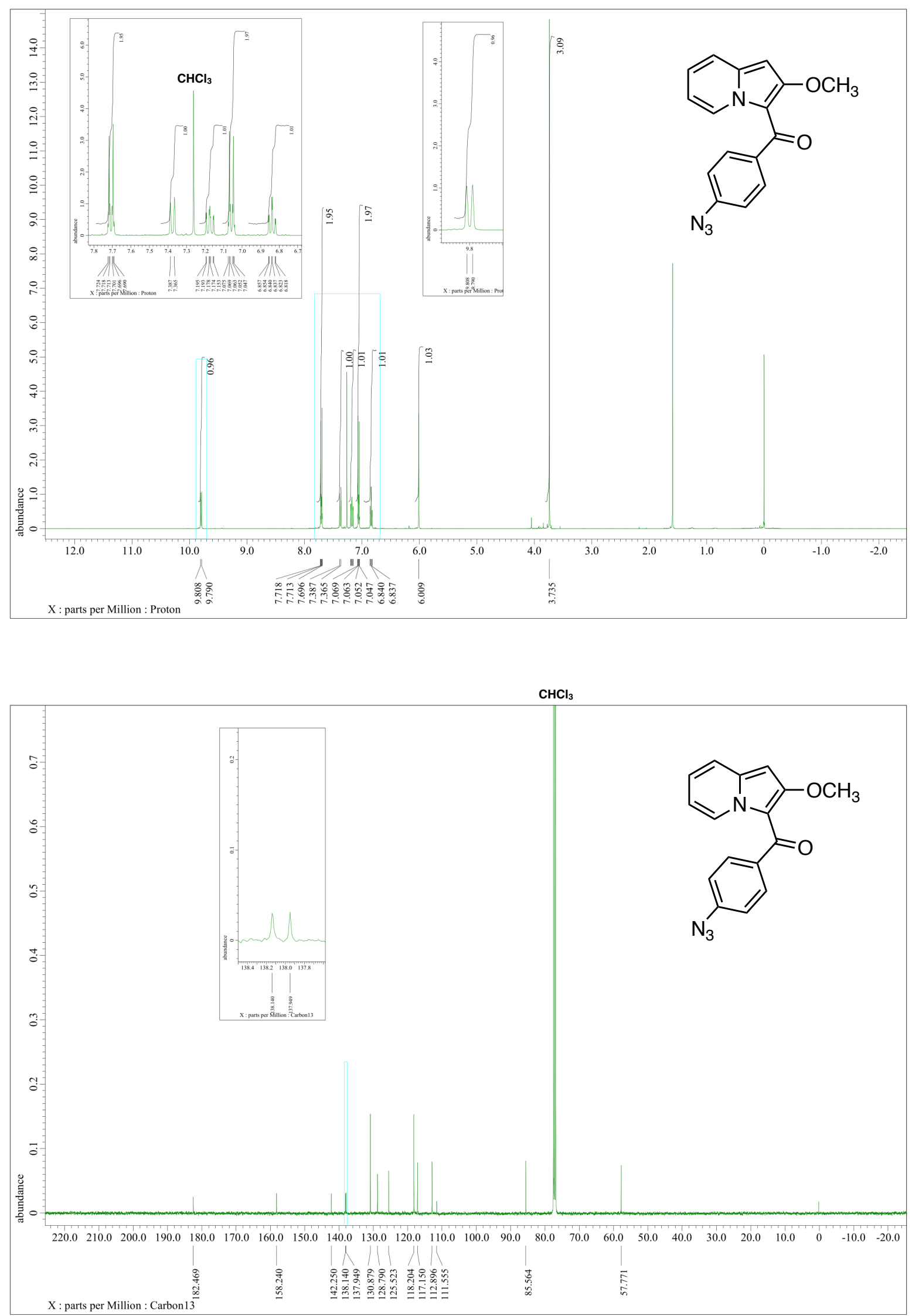
${ }^{1} \mathrm{H}$ NMR (400 MHz) and ${ }^{13} \mathrm{C}\left\{{ }^{1} \mathrm{H}\right\}$ NMR (100 MHz) spectra of $8\left(\mathrm{CDCl}_{3}\right)$
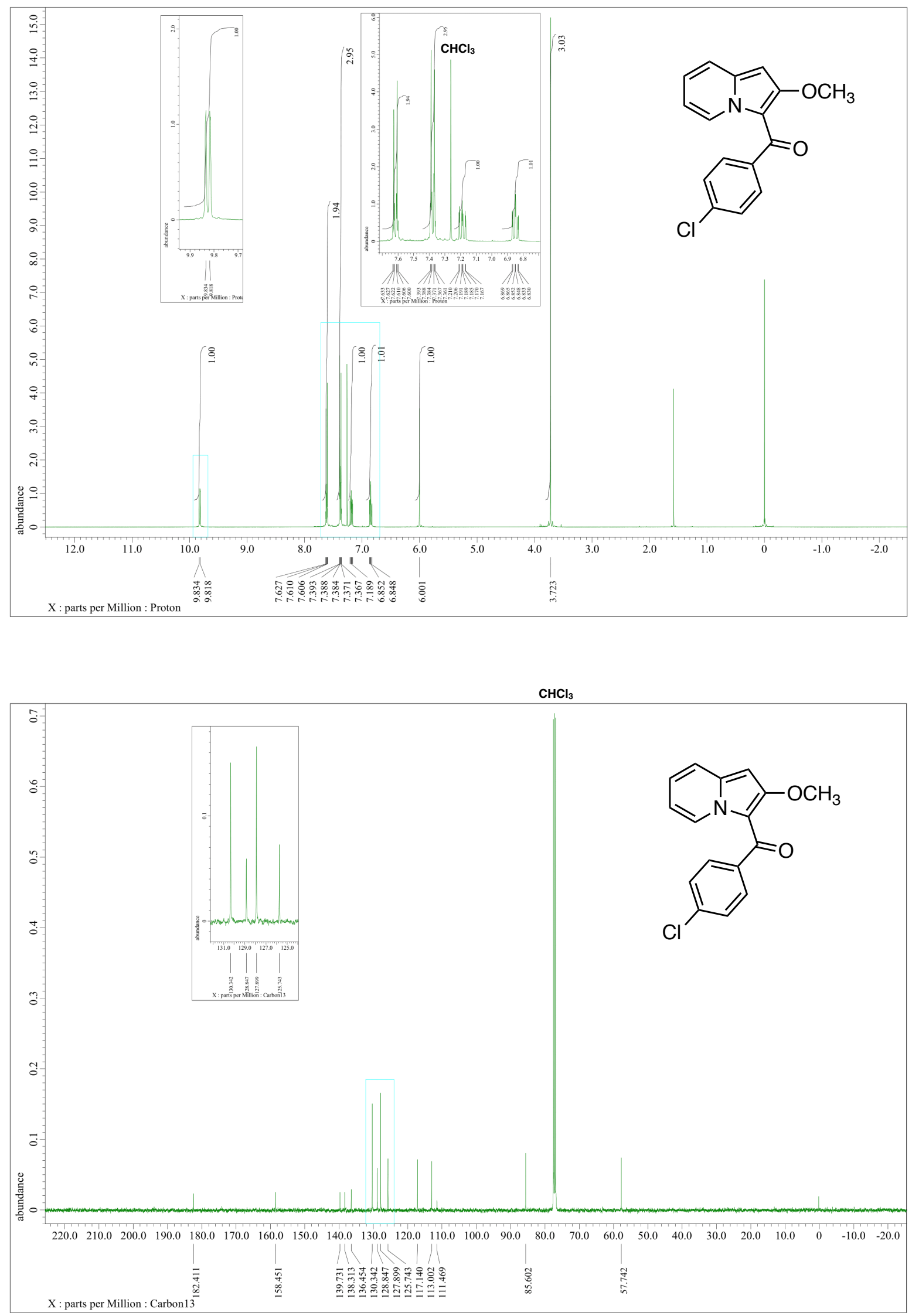
${ }^{1} \mathrm{H}$ NMR (400 MHz) and ${ }^{13} \mathrm{C}\left\{{ }^{1} \mathrm{H}\right\}$ NMR (100 MHz) spectra of $9\left(\mathrm{CDCl}_{3}\right)$
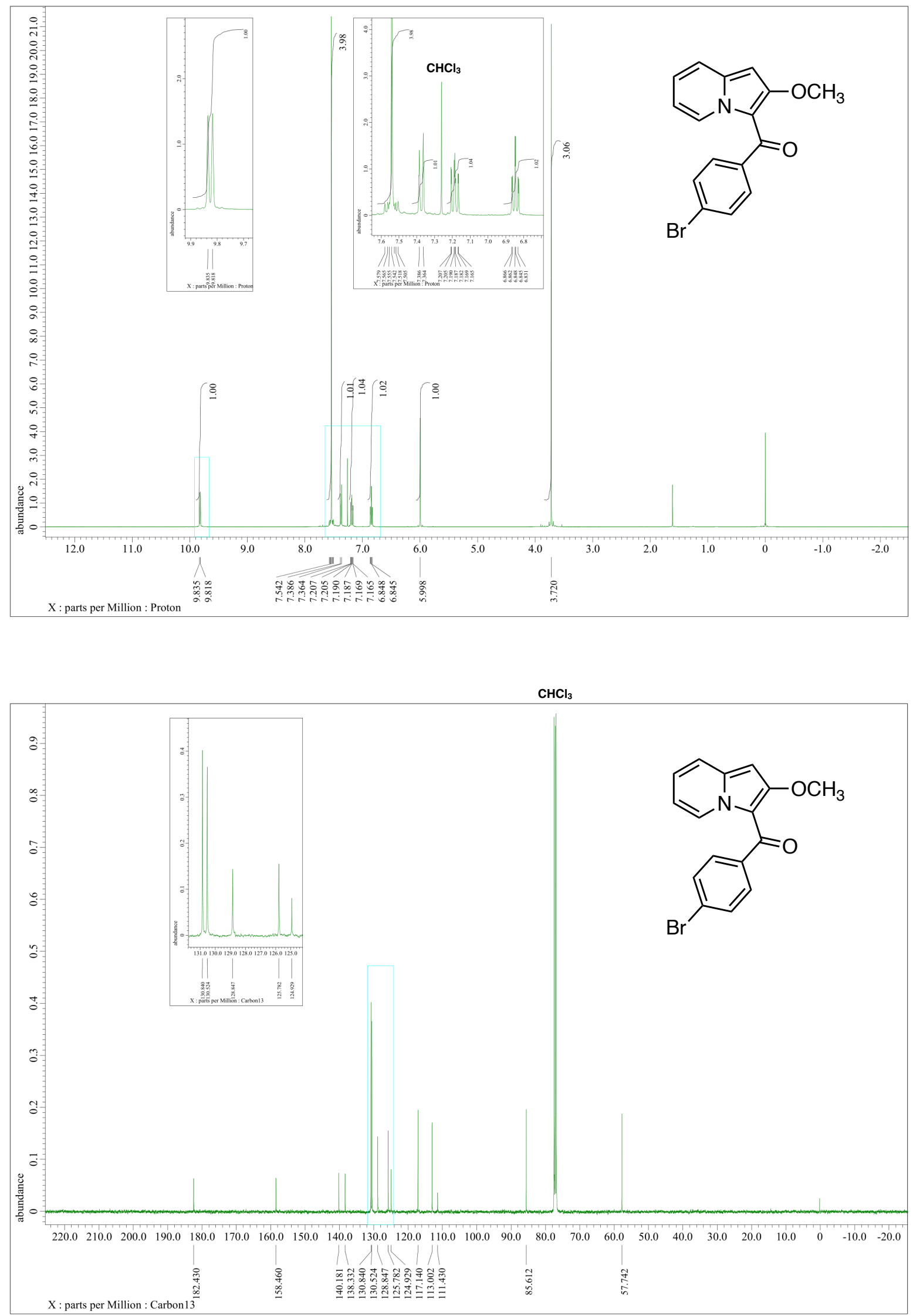
${ }^{1} \mathrm{H}$ NMR $(400 \mathrm{MHz})$ and ${ }^{13} \mathrm{C}\left\{{ }^{1} \mathrm{H}\right\}$ NMR $(100 \mathrm{MHz})$ spectra of $\mathbf{1 0}\left(\mathrm{CDCl}_{3}\right)$
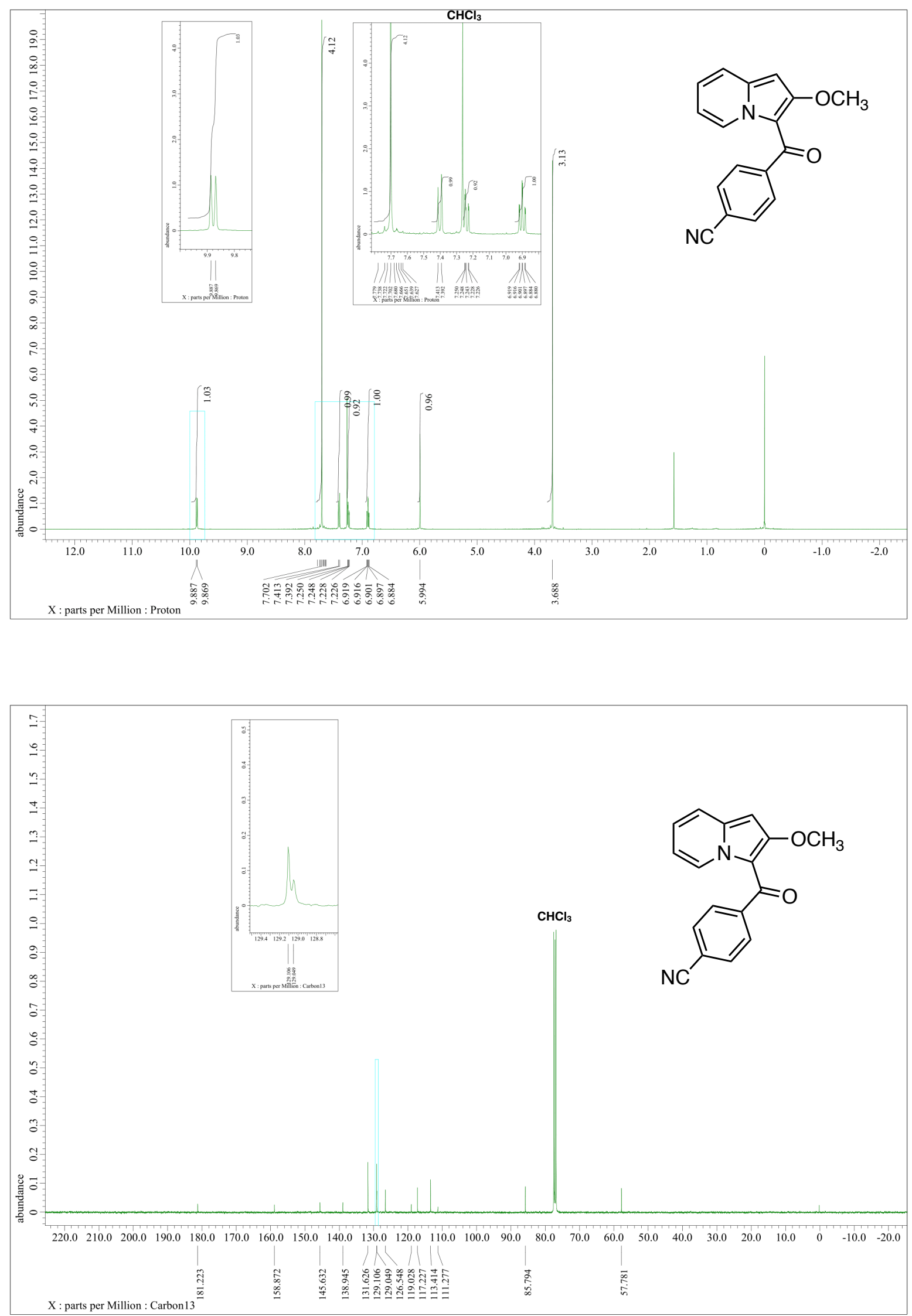
${ }^{1} \mathrm{H}$ NMR (400 MHz) and ${ }^{13} \mathrm{C}\left\{{ }^{1} \mathrm{H}\right\}$ NMR (100 MHz) spectra of $11\left(\mathrm{CDCl}_{3}\right)$
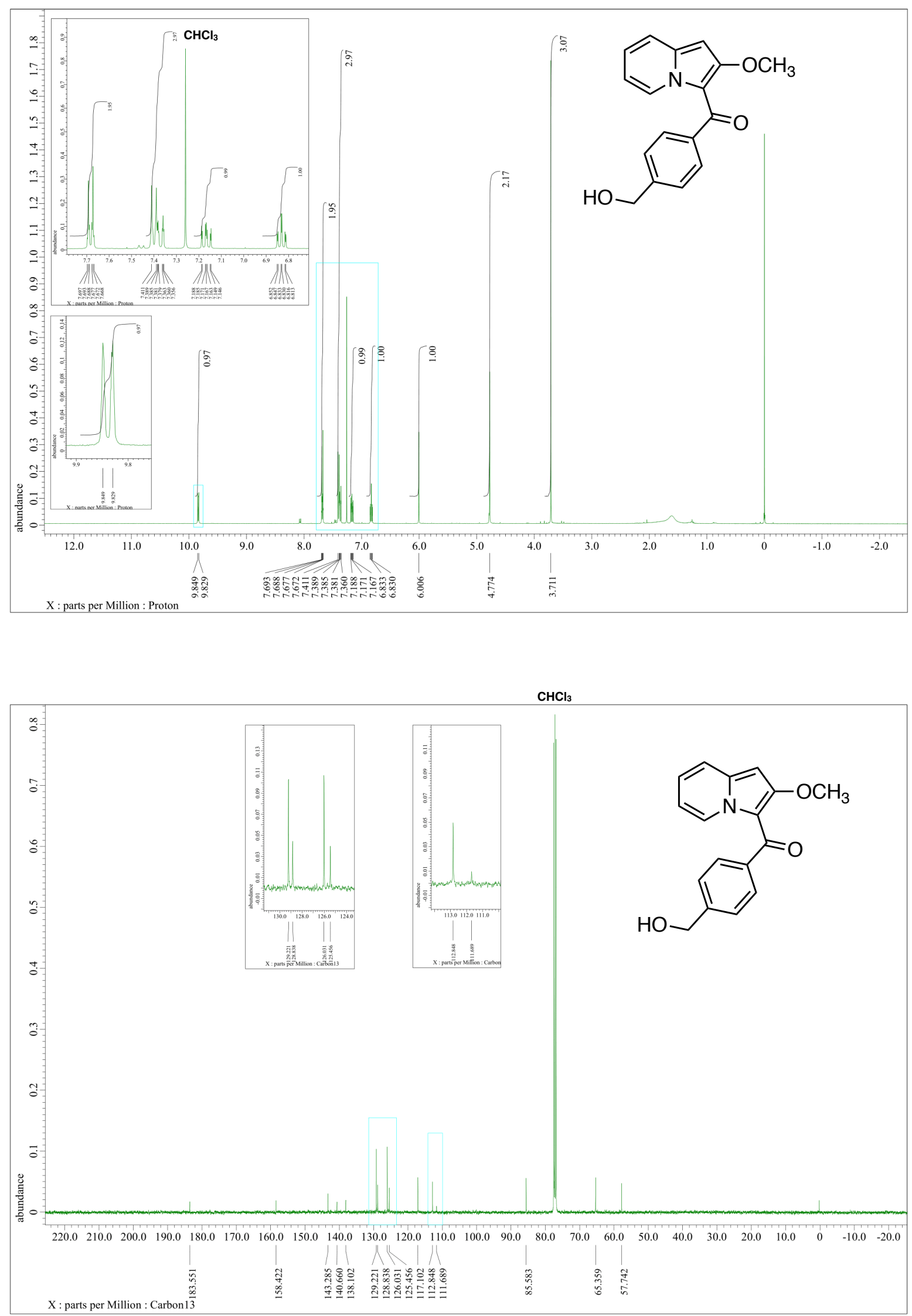
${ }^{1} \mathrm{H}$ NMR $(400 \mathrm{MHz})$ and ${ }^{13} \mathrm{C}\left\{{ }^{1} \mathrm{H}\right\}$ NMR $(100 \mathrm{MHz})$ spectra of $12\left(\mathrm{CDCl}_{3}\right)$
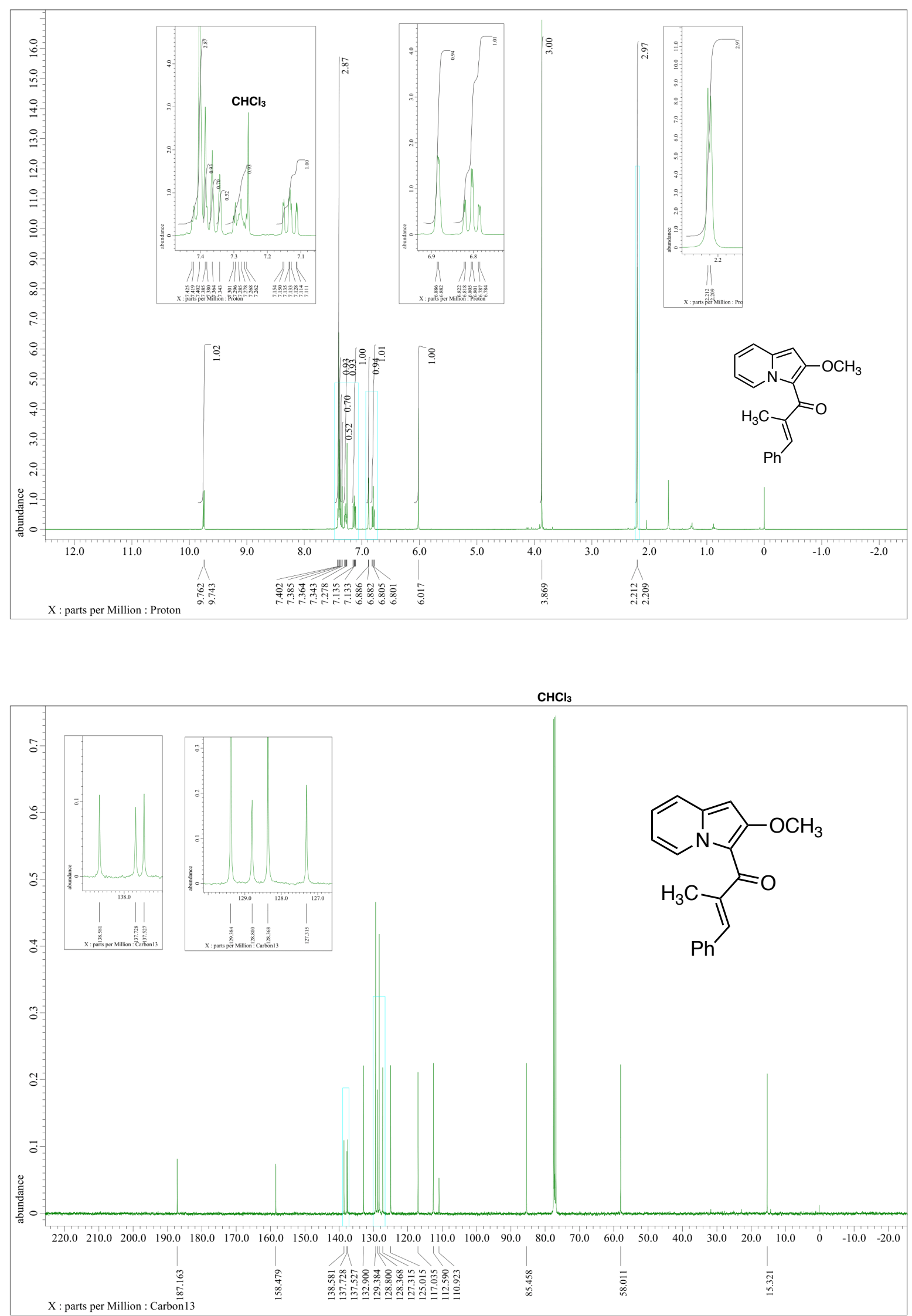
${ }^{1} \mathrm{H}$ NMR $(400 \mathrm{MHz})$ and ${ }^{13} \mathrm{C}\left\{{ }^{1} \mathrm{H}\right\}$ NMR $(100 \mathrm{MHz})$ spectra of $\mathbf{1 3}\left(\mathrm{CDCl}_{3}\right)$
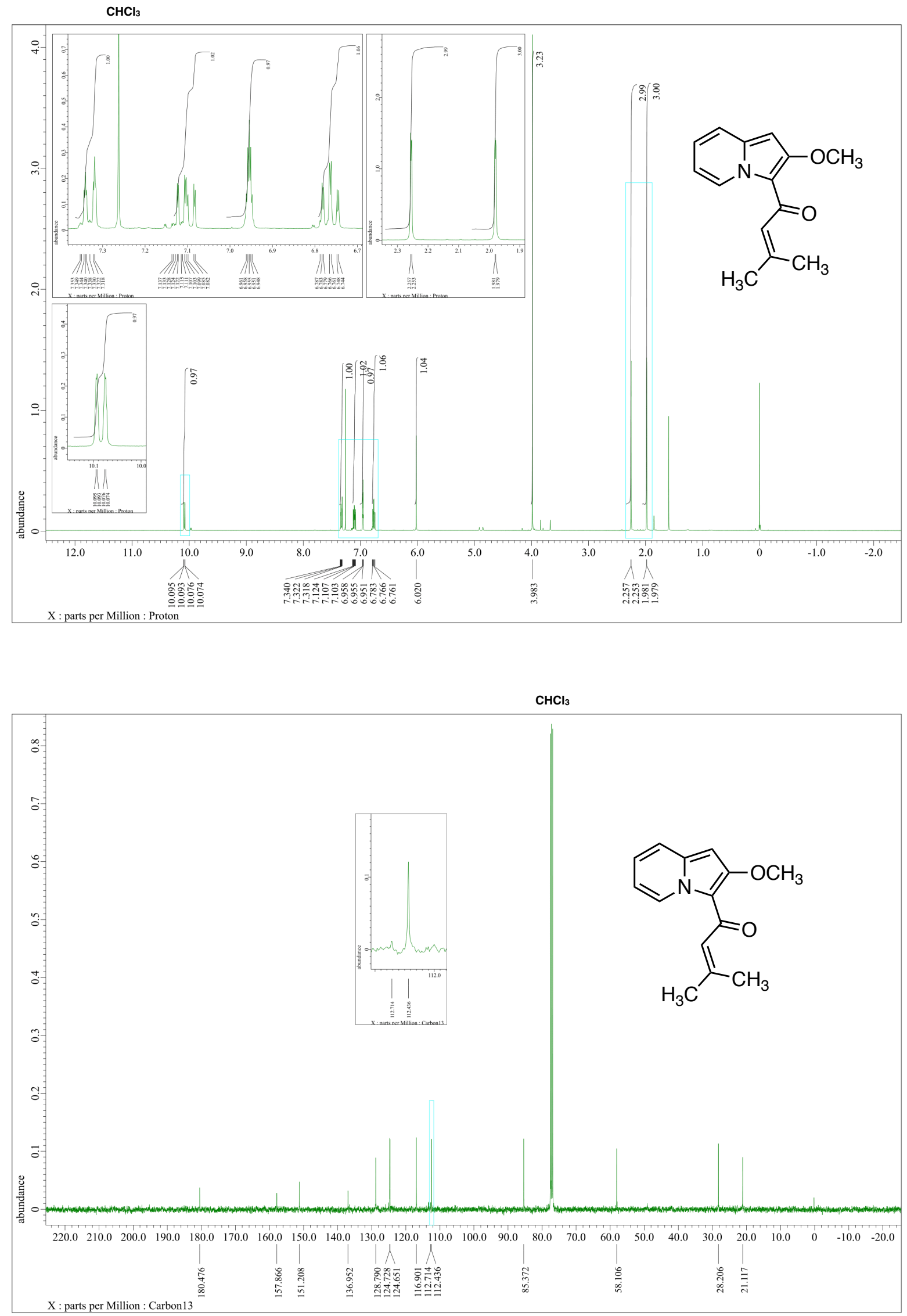
${ }^{1} \mathrm{H}$ NMR $(400 \mathrm{MHz})$ and ${ }^{13} \mathrm{C}\left\{{ }^{1} \mathrm{H}\right\}$ NMR $(100 \mathrm{MHz})$ spectra of $14\left(\mathrm{CDCl}_{3}\right)$
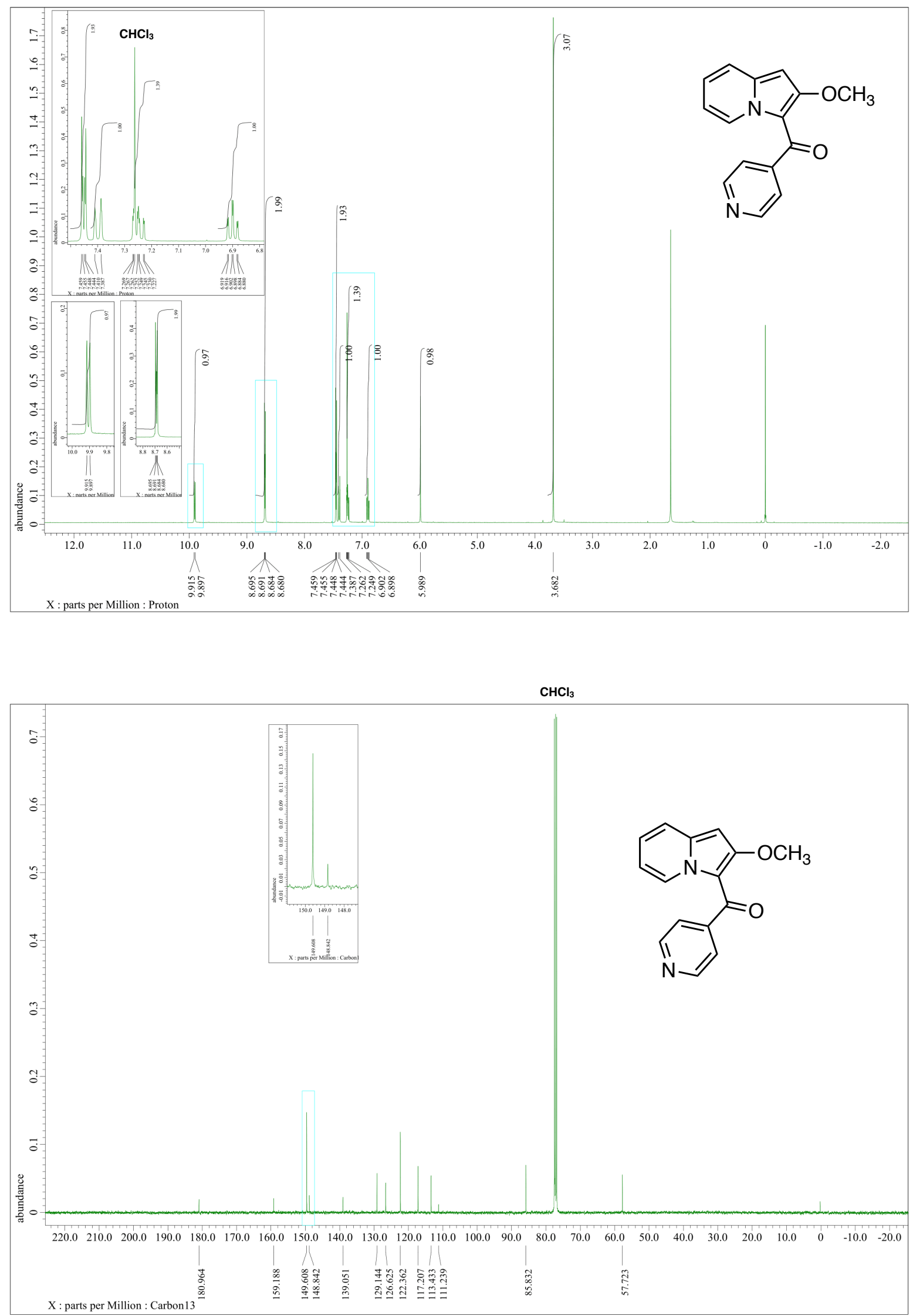
${ }^{1} \mathrm{H}$ NMR $(400 \mathrm{MHz})$ and ${ }^{13} \mathrm{C}\left\{{ }^{1} \mathrm{H}\right\}$ NMR $(100 \mathrm{MHz})$ spectra of $\mathbf{1 5}\left(\mathrm{CDCl}_{3}\right)$
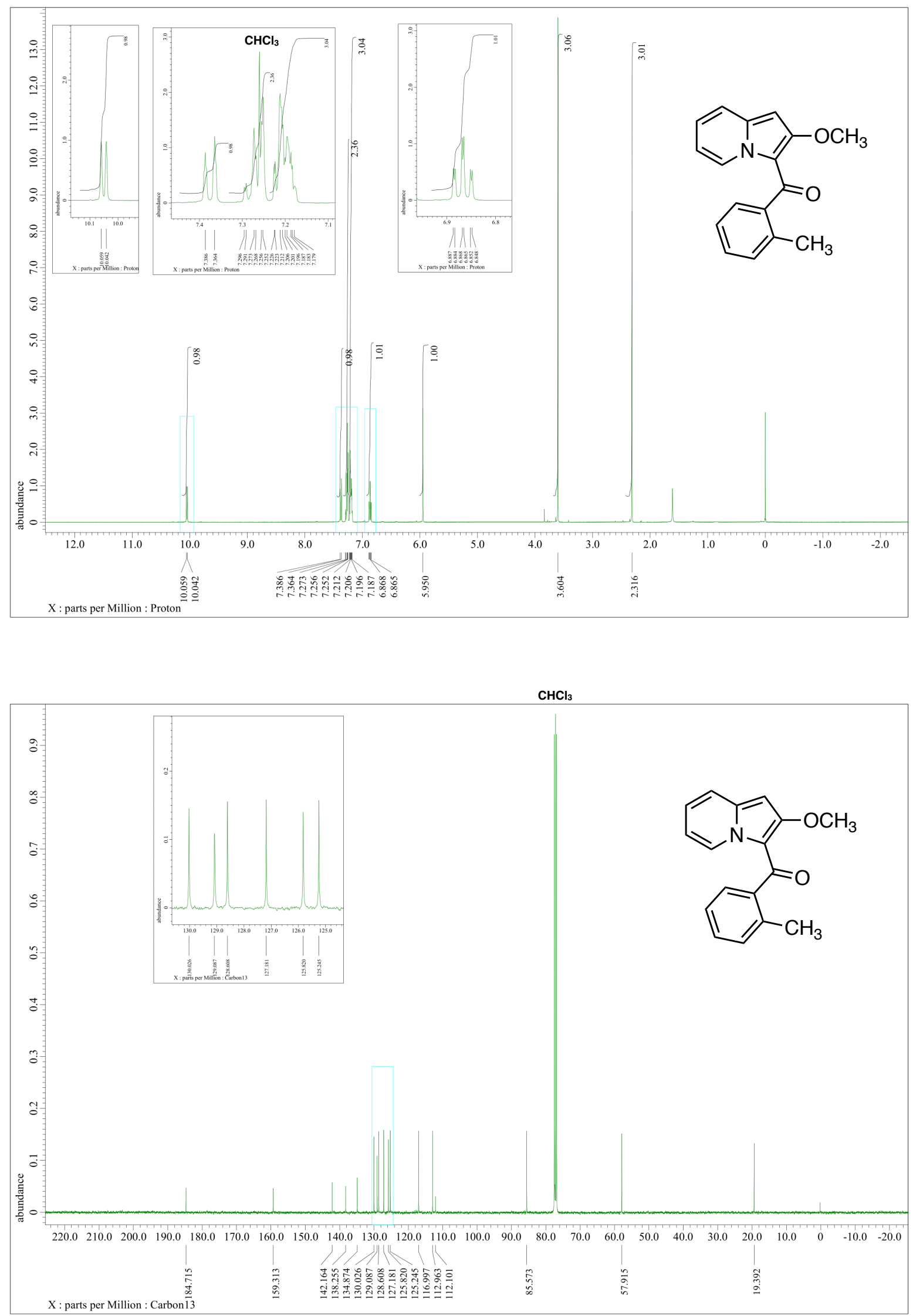
${ }^{1} \mathrm{H}$ NMR $(400 \mathrm{MHz})$ and ${ }^{13} \mathrm{C}\left\{{ }^{1} \mathrm{H}\right\}$ NMR $(100 \mathrm{MHz})$ spectra of $\mathbf{1 6}\left(\mathrm{CDCl}_{3}\right)$

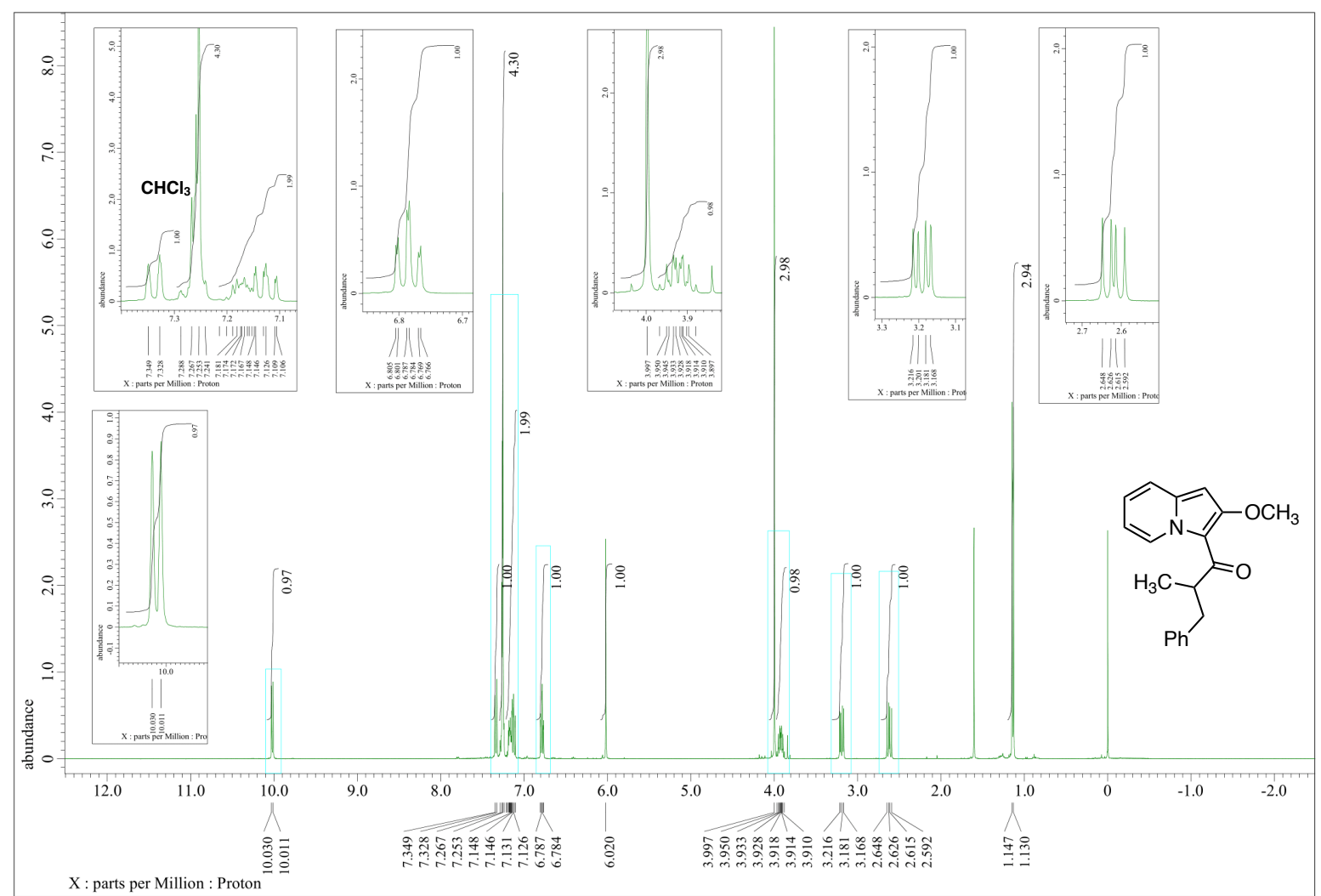

$\mathrm{CHCl}_{3}$

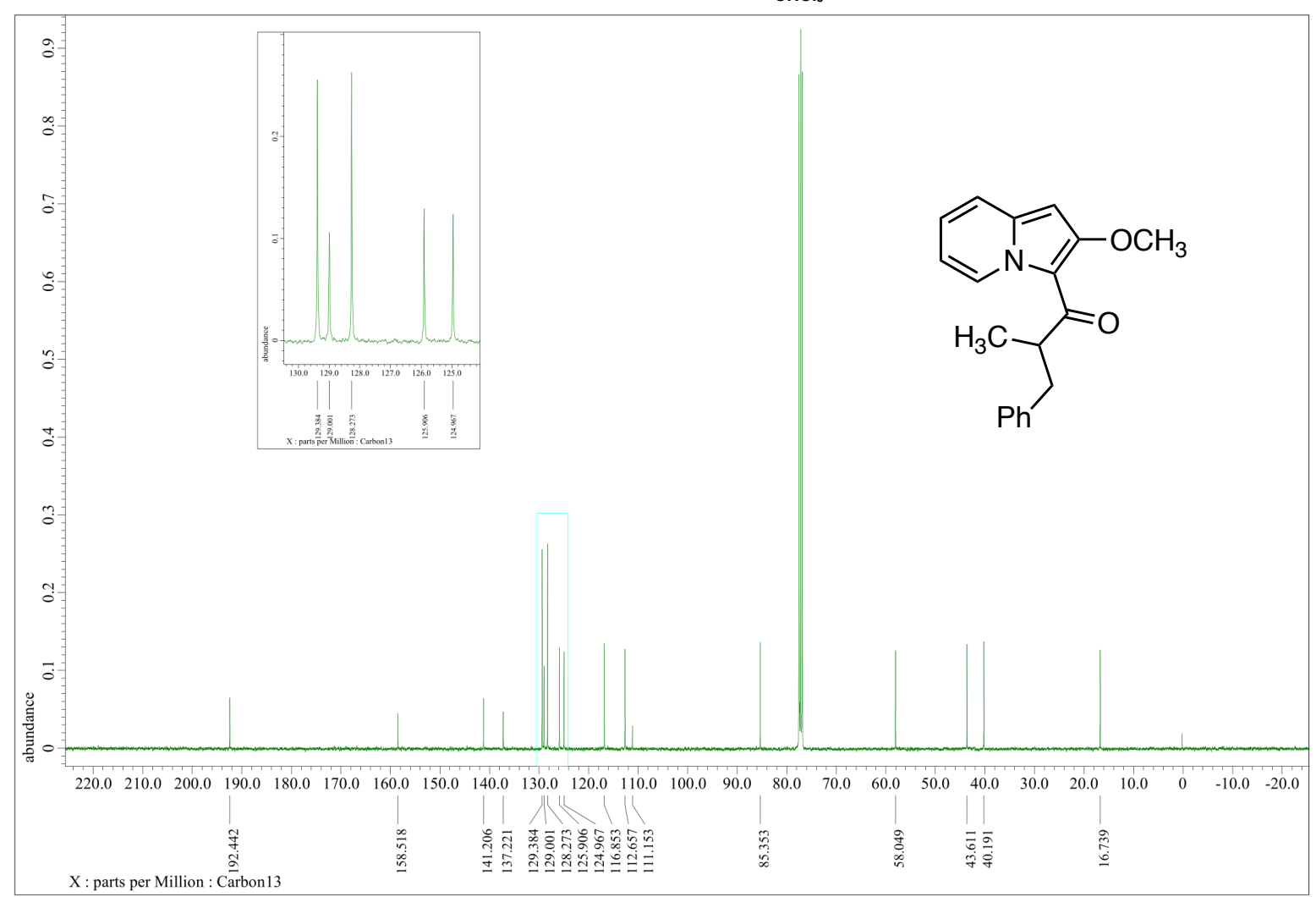


${ }^{1} \mathrm{H}$ NMR (400 MHz) and ${ }^{13} \mathrm{C}\left\{{ }^{1} \mathrm{H}\right\}$ NMR (100 MHz) spectra of 2-methoxy-5-methylindolizine $\left(\mathrm{CDCl}_{3}\right)$
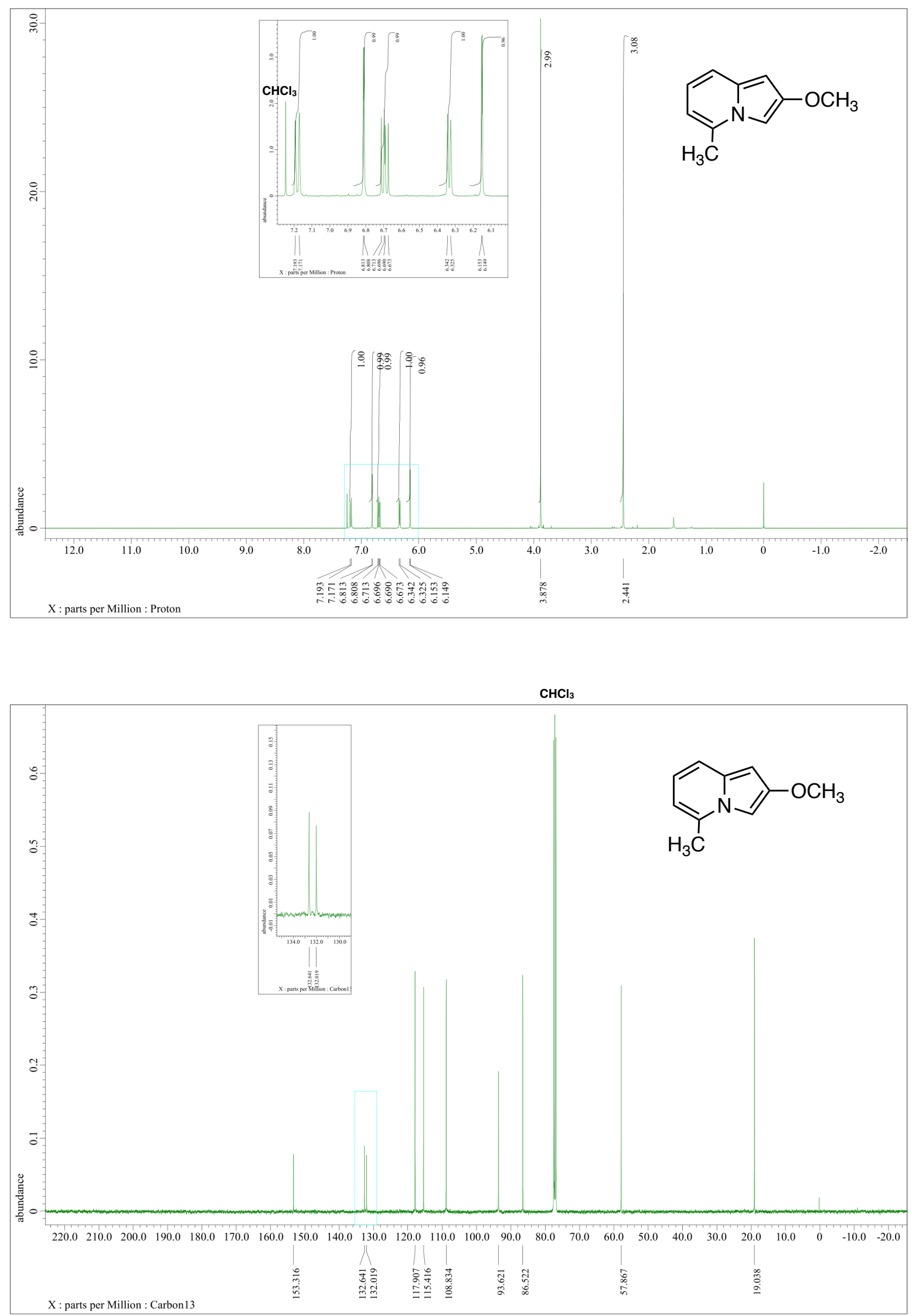
${ }^{1} \mathrm{H}$ NMR $(400 \mathrm{MHz})$ and ${ }^{13} \mathrm{C}\left\{{ }^{1} \mathrm{H}\right\}$ NMR $(100 \mathrm{MHz})$ spectra of $17\left(\mathrm{CDCl}_{3}\right)$
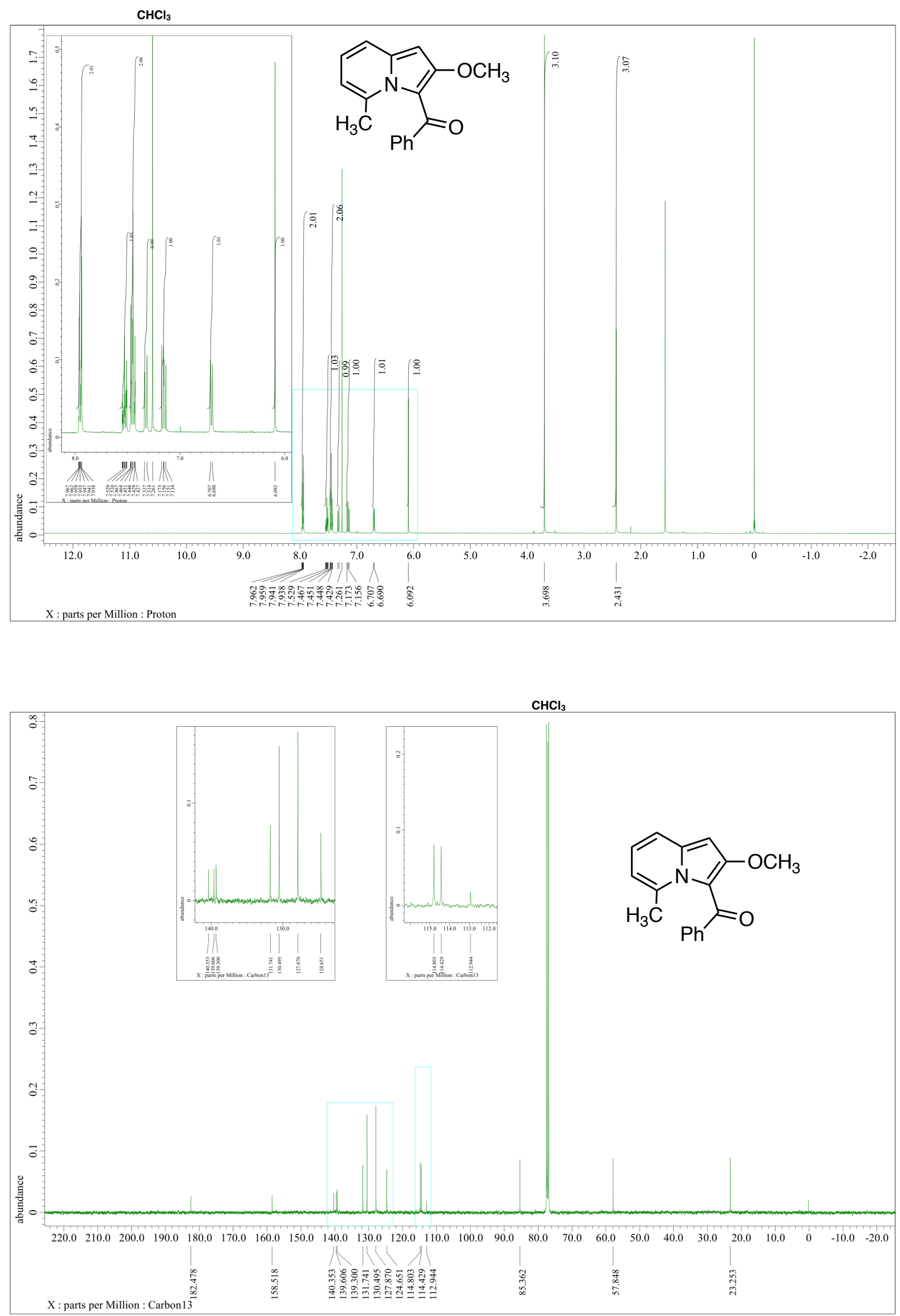
${ }^{1} \mathrm{H}$ NMR (400 MHz) and ${ }^{13} \mathrm{C}\left\{{ }^{1} \mathrm{H}\right\}$ NMR (100 MHz) spectra of 2-methoxy-1-methylindolizine $\left(\mathrm{CDCl}_{3}\right)$
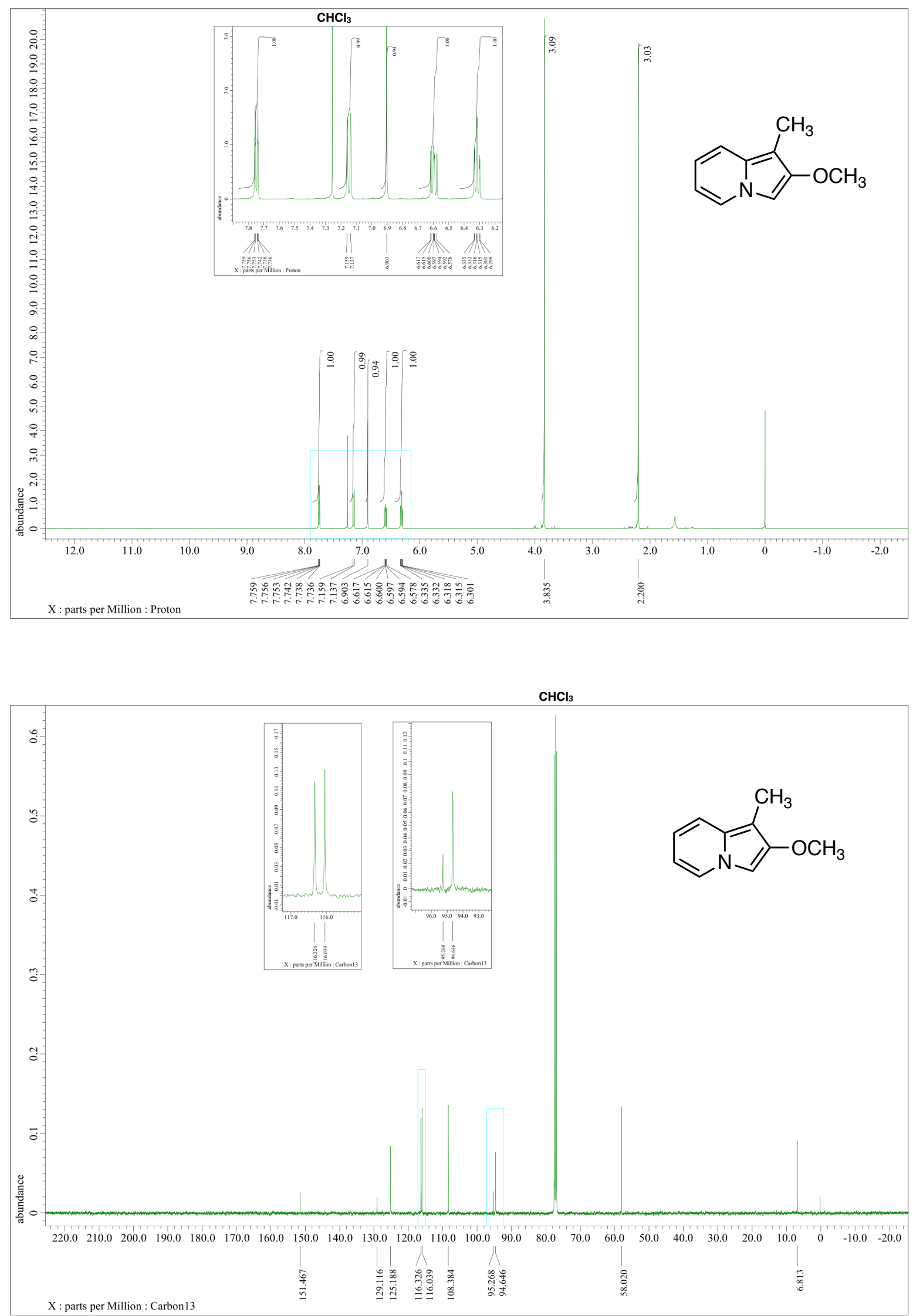
${ }^{1} \mathrm{H}$ NMR $(400 \mathrm{MHz})$ and ${ }^{13} \mathrm{C}\left\{{ }^{1} \mathrm{H}\right\}$ NMR $(100 \mathrm{MHz})$ spectra of $\mathbf{1 8}\left(\mathrm{CDCl}_{3}\right)$
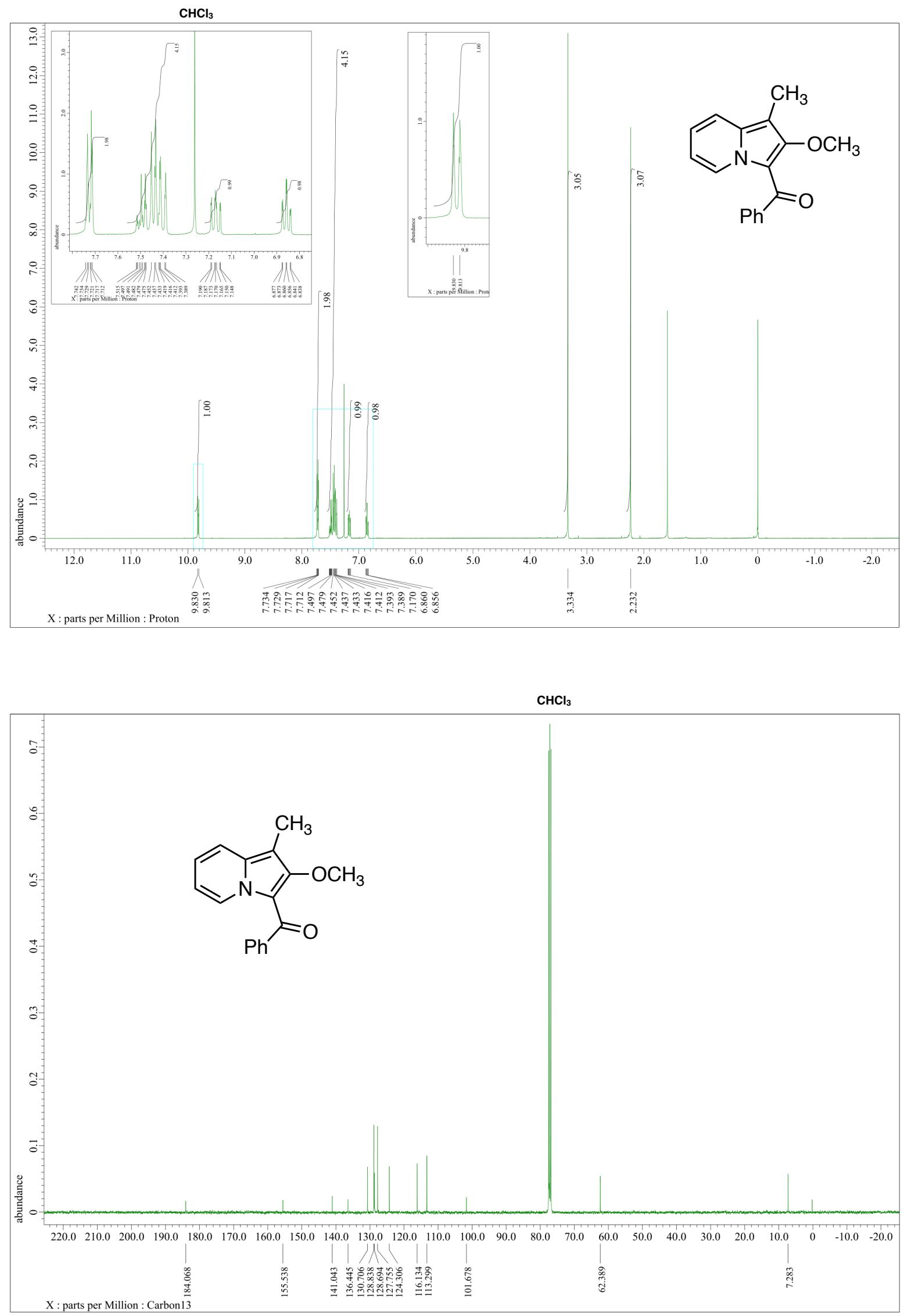
${ }^{1} \mathrm{H}$ NMR $(400 \mathrm{MHz})$ and ${ }^{13} \mathrm{C}\left\{{ }^{1} \mathrm{H}\right\}$ NMR $(100 \mathrm{MHz})$ spectra of $19\left(\mathrm{CDCl}_{3}\right)$
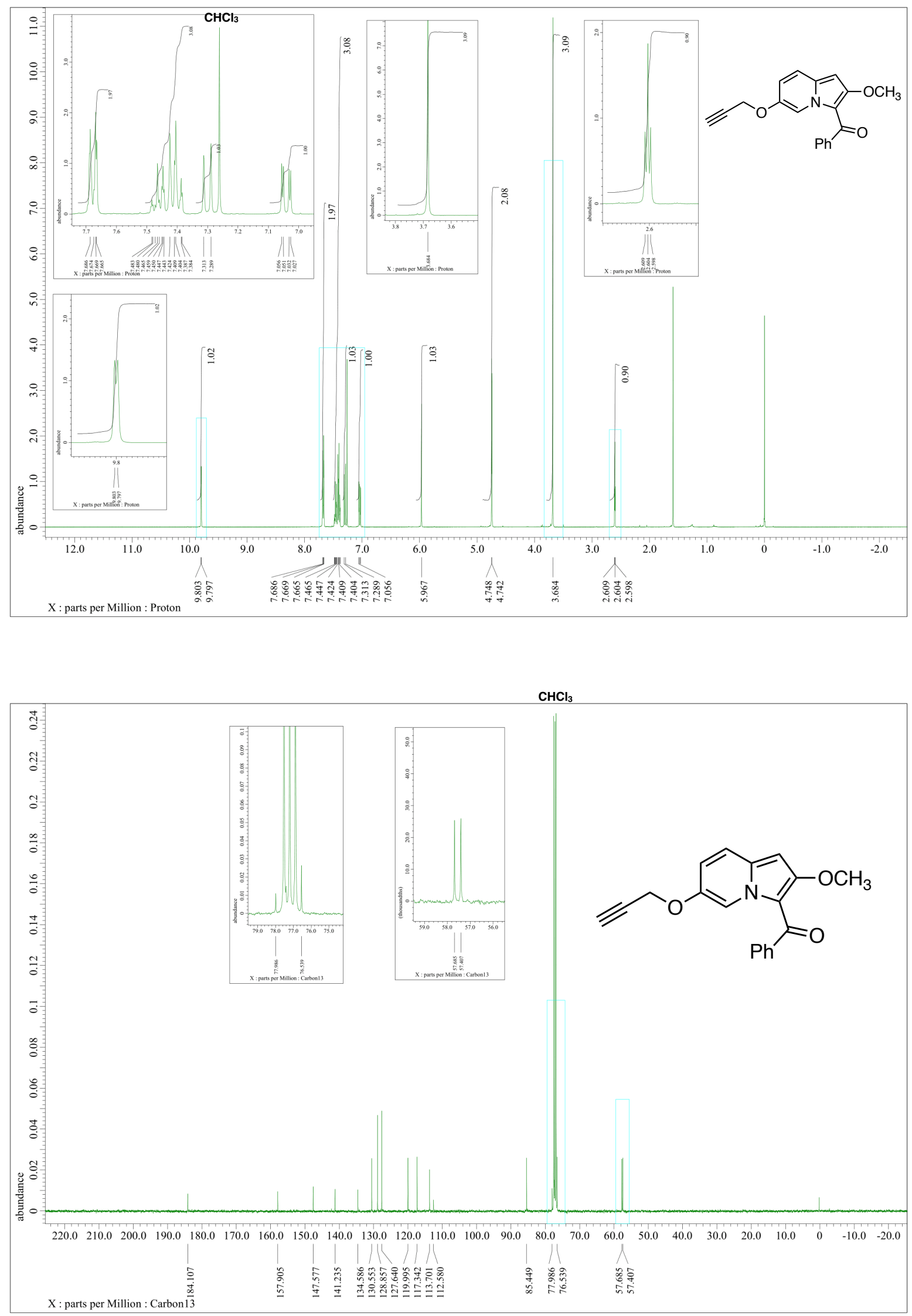
${ }^{1} \mathrm{H}$ NMR $(400 \mathrm{MHz})$ and ${ }^{13} \mathrm{C}\left\{{ }^{1} \mathrm{H}\right\}$ NMR $(100 \mathrm{MHz})$ spectra of $20\left(\mathrm{CDCl}_{3}\right)$

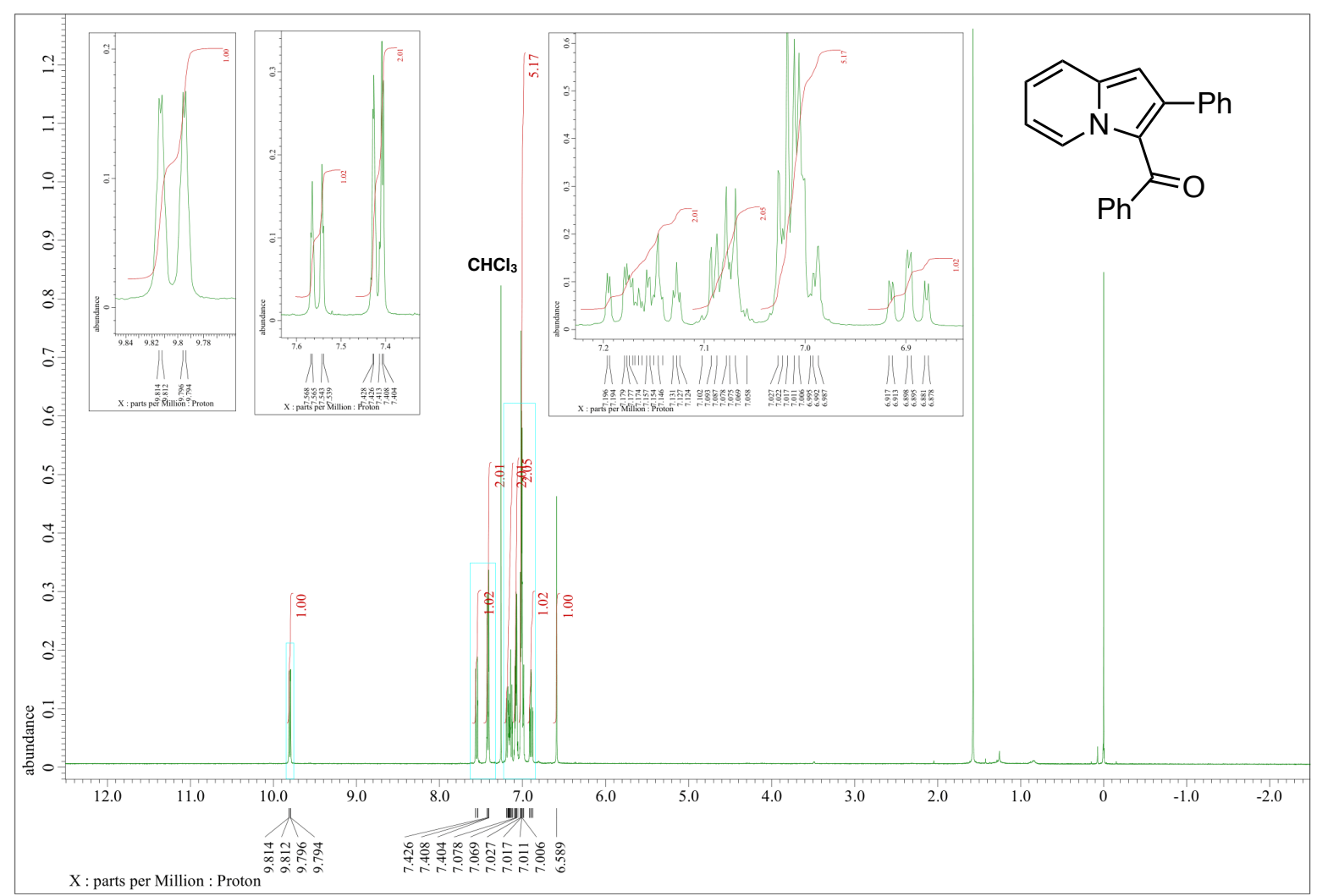

$\mathrm{CHCl}_{3}$

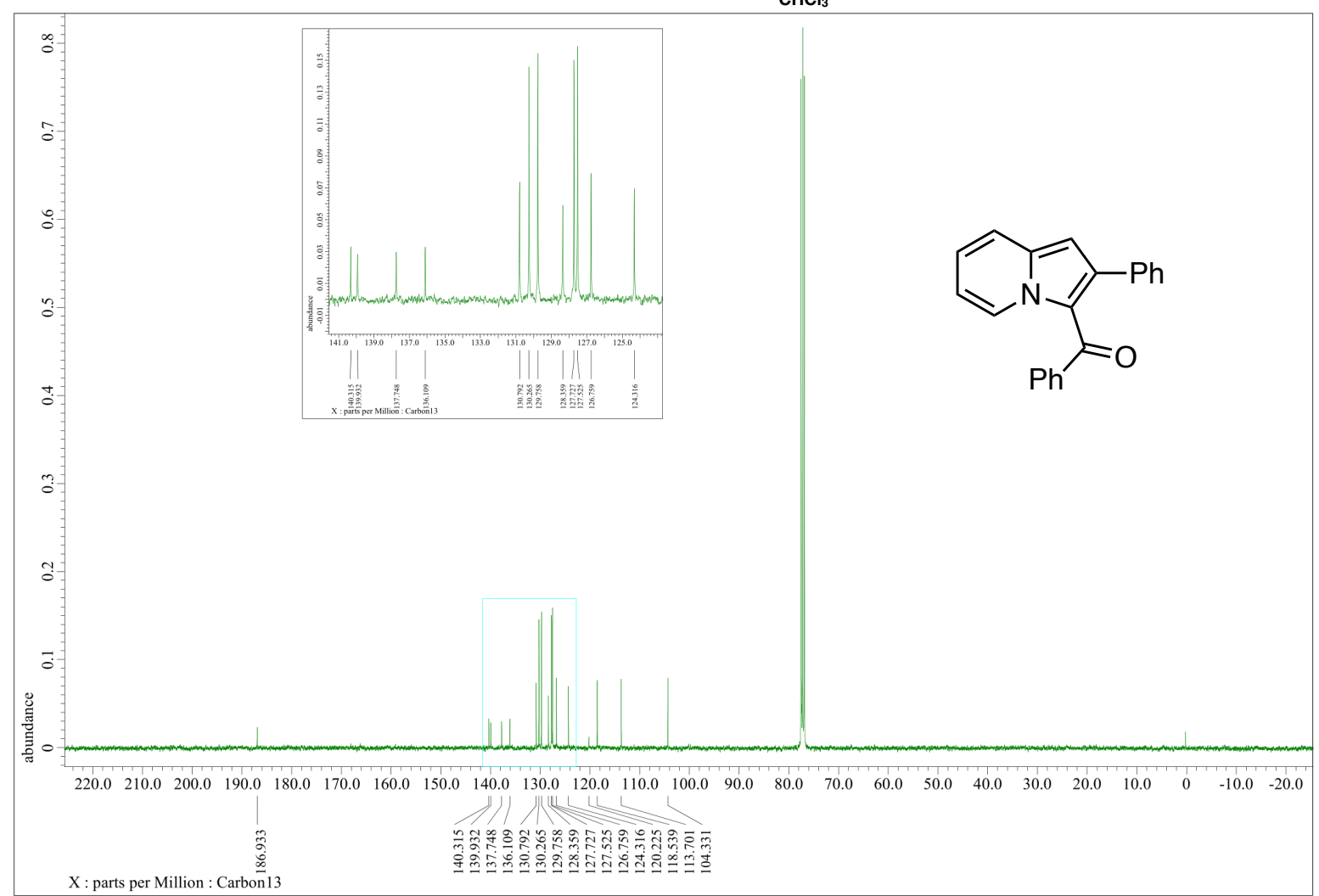


${ }^{1} \mathrm{H}$ NMR $(400 \mathrm{MHz})$ and ${ }^{13} \mathrm{C}\left\{{ }^{1} \mathrm{H}\right\}$ NMR $(100 \mathrm{MHz})$ spectra of $21\left(\mathrm{CDCl}_{3}\right)$
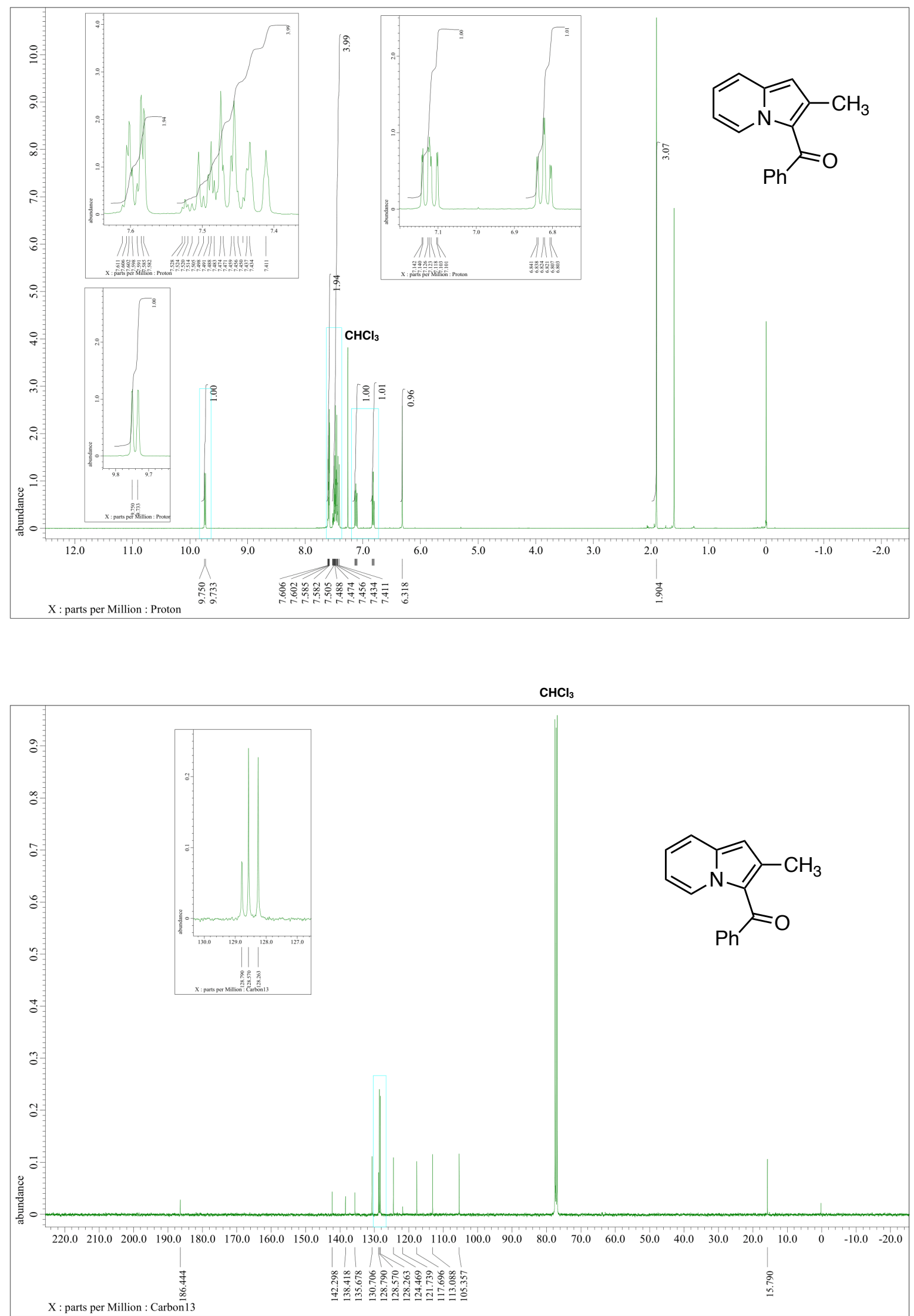
${ }^{1} \mathrm{H}$ NMR $(400 \mathrm{MHz})$ and ${ }^{13} \mathrm{C}\left\{{ }^{1} \mathrm{H}\right\}$ NMR $(100 \mathrm{MHz})$ spectra of $22\left(\mathrm{CDCl}_{3}\right)$
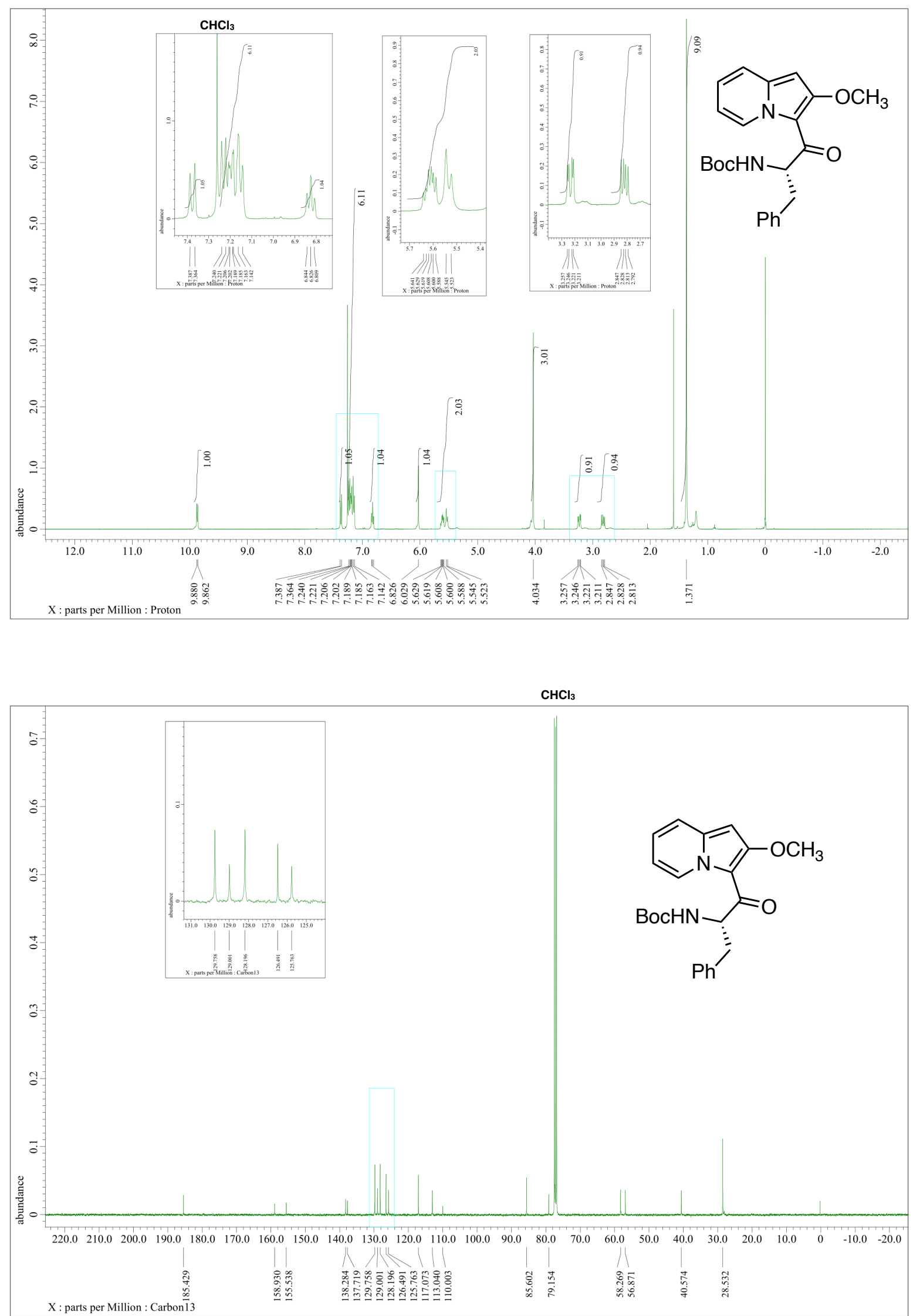
${ }^{1} \mathrm{H}$ NMR (400 MHz) and ${ }^{13} \mathrm{C}\left\{{ }^{1} \mathrm{H}\right\}$ NMR $(100 \mathrm{MHz})$ spectra of $\mathrm{rac}-22\left(\mathrm{CDCl}_{3}\right)$
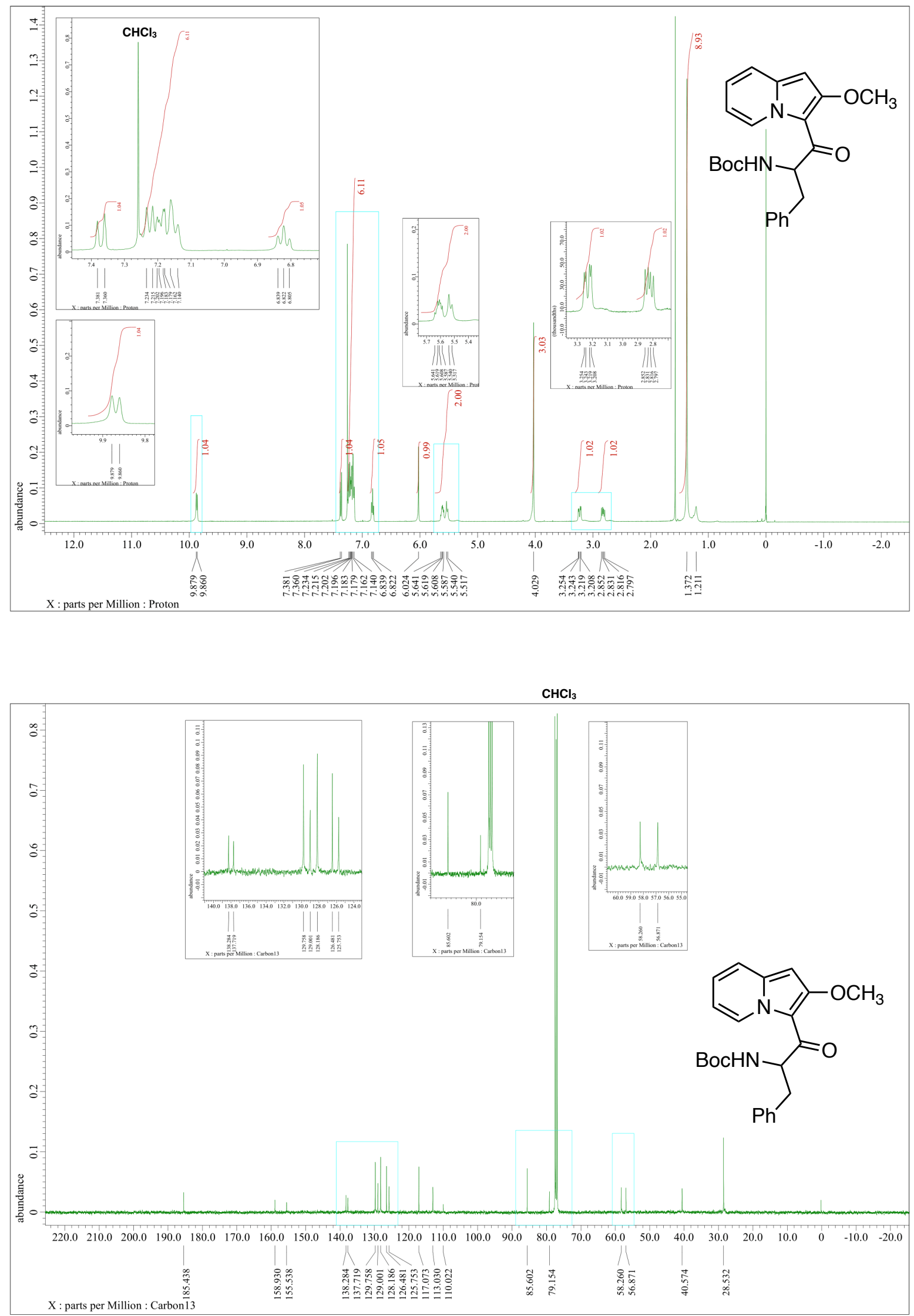
${ }^{1} \mathrm{H}$ NMR (400 MHz) and ${ }^{13} \mathrm{C}\left\{{ }^{1} \mathrm{H}\right\}$ NMR (100 MHz) spectra of 23 (DMSO- $d_{6}$ )
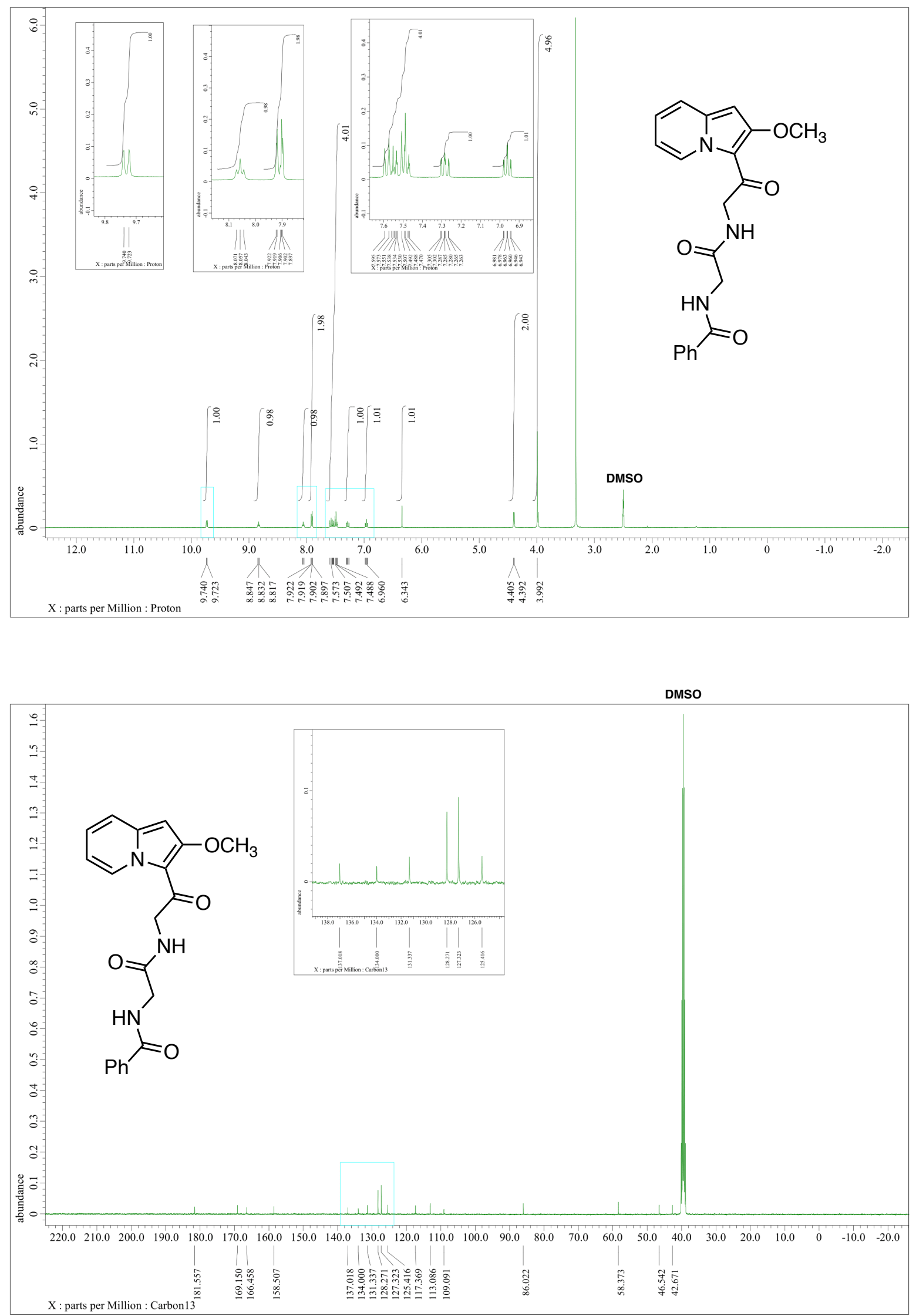
${ }^{1} \mathrm{H}$ NMR $(400 \mathrm{MHz})$ and ${ }^{13} \mathrm{C}\left\{{ }^{1} \mathrm{H}\right\}$ NMR $(100 \mathrm{MHz})$ spectra of $24\left(\mathrm{CDCl}_{3}\right)$
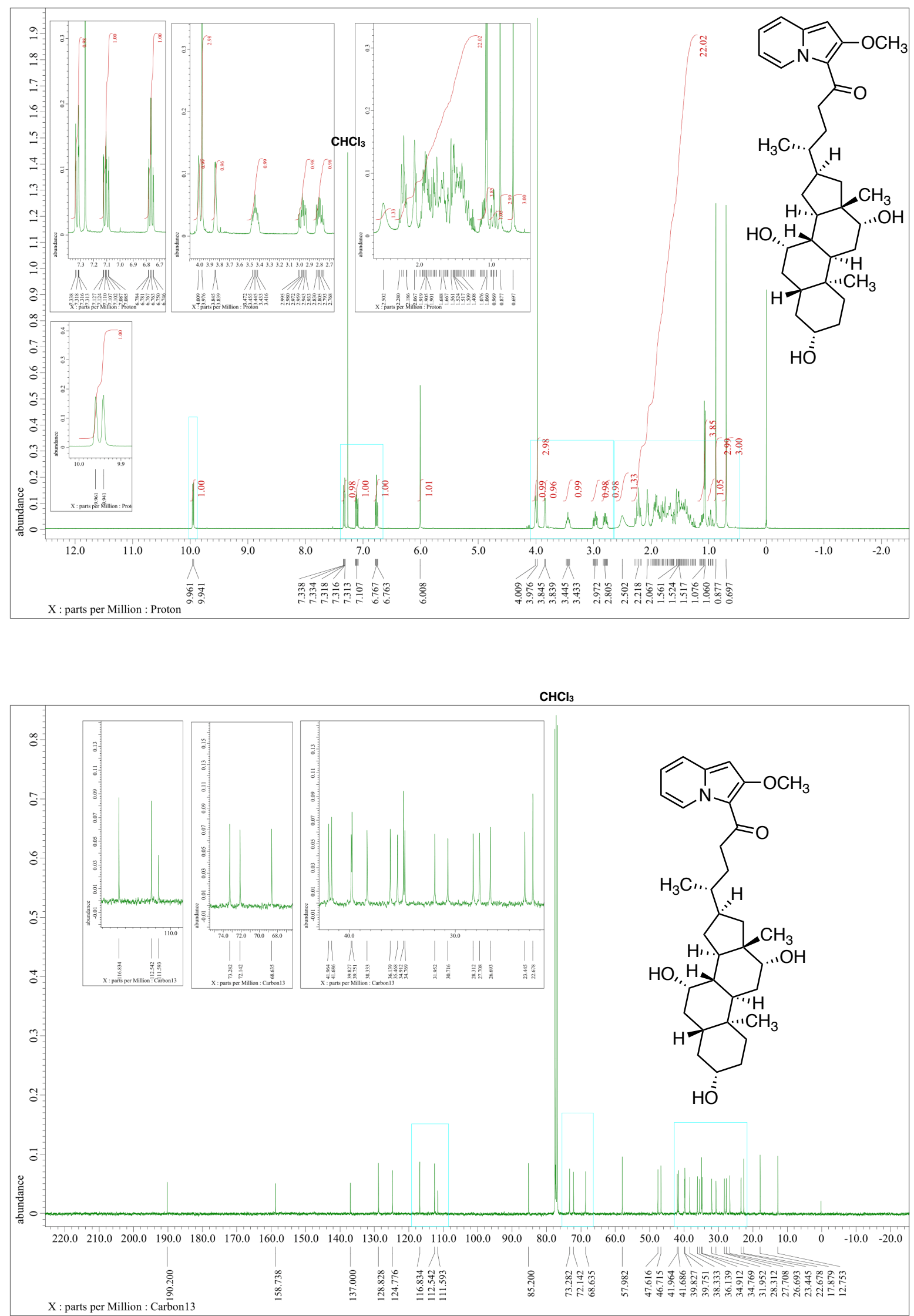
${ }^{1} \mathrm{H}$ NMR $(400 \mathrm{MHz})$ and ${ }^{13} \mathrm{C}\left\{{ }^{1} \mathrm{H}\right\}$ NMR $(100 \mathrm{MHz})$ spectra of $25\left(\mathrm{CDCl}_{3}\right)$
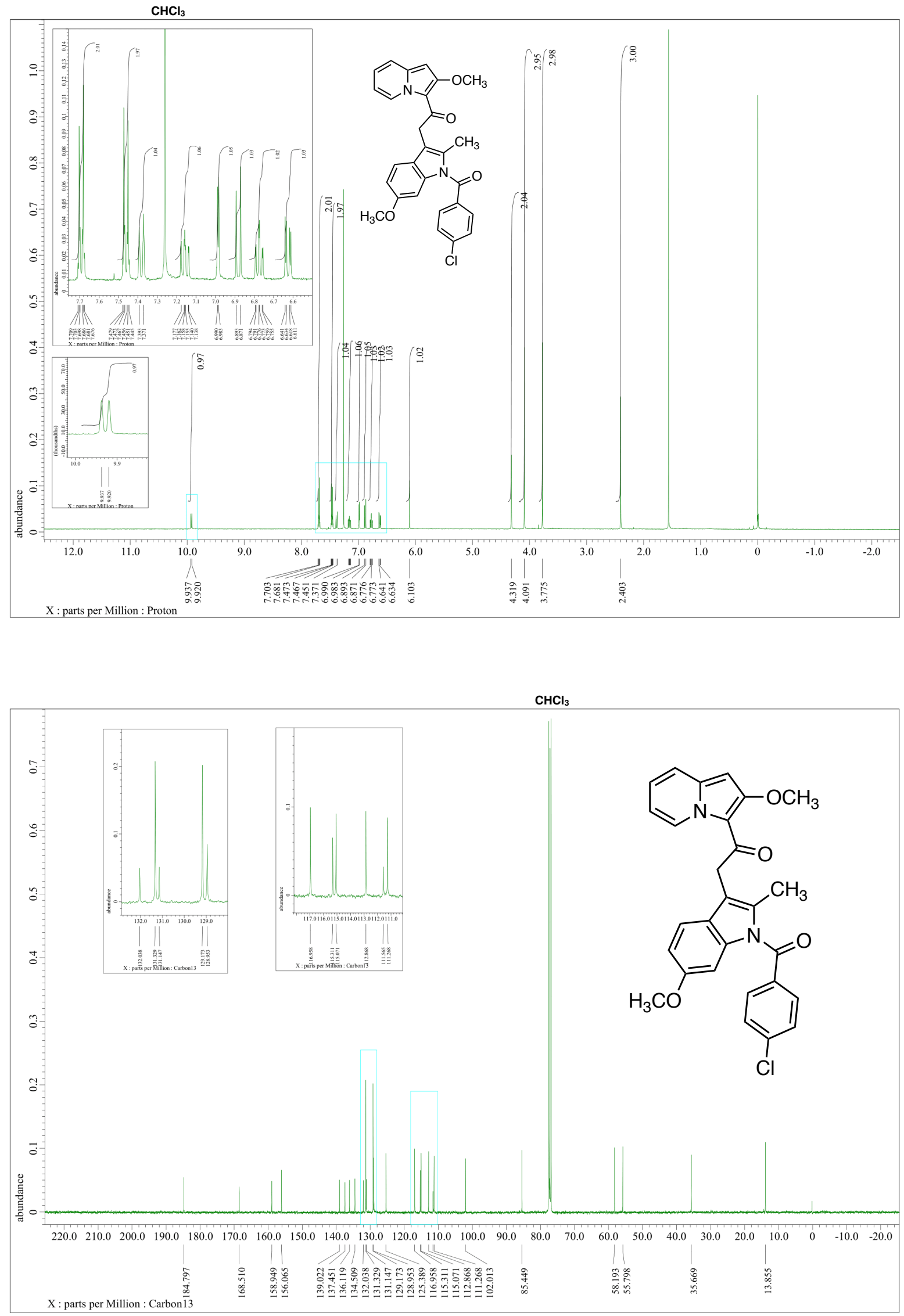
${ }^{1} \mathrm{H}$ NMR $(400 \mathrm{MHz})$ and ${ }^{13} \mathrm{C}\left\{{ }^{1} \mathrm{H}\right\}$ NMR $(100 \mathrm{MHz})$ spectra of $26\left(\mathrm{CDCl}_{3}\right)$
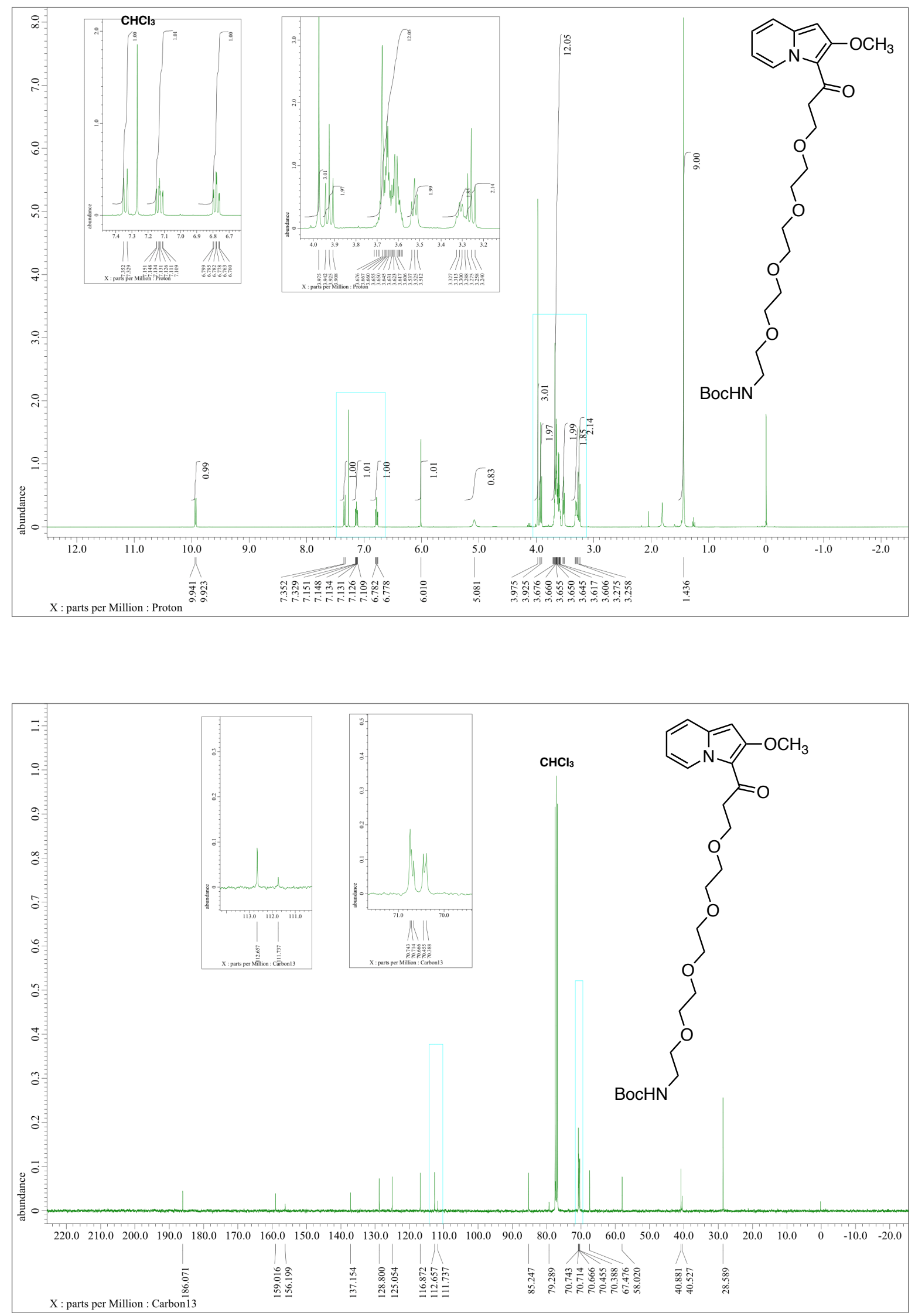
${ }^{1} \mathrm{H}$ NMR $(400 \mathrm{MHz})$ and ${ }^{13} \mathrm{C}\left\{{ }^{1} \mathrm{H}\right\}$ NMR $(100 \mathrm{MHz})$ spectra of $41\left(\mathrm{CDCl}_{3}\right)$
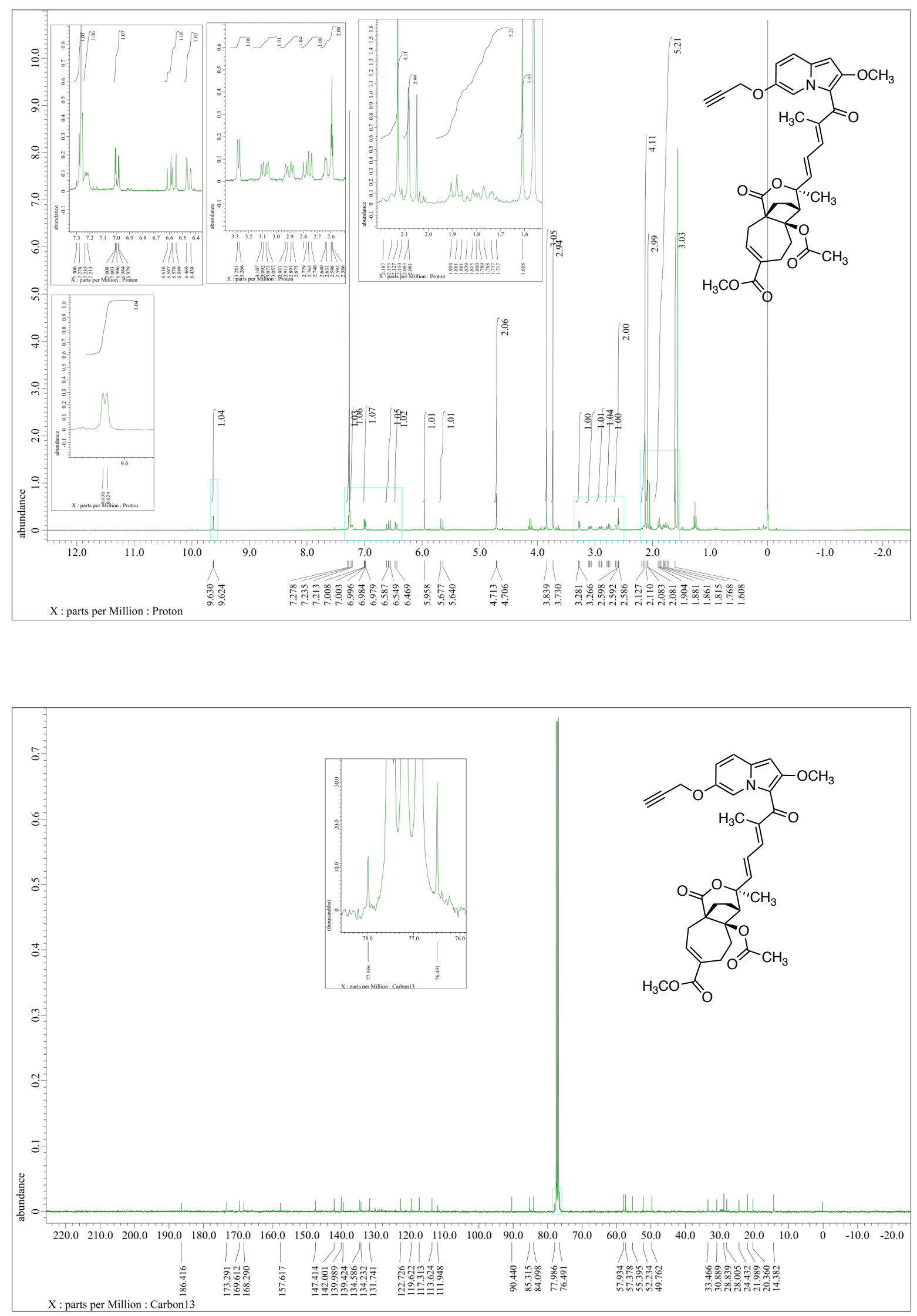
${ }^{1} \mathrm{H}$ NMR $(400 \mathrm{MHz})$ and ${ }^{13} \mathrm{C}\left\{{ }^{1} \mathrm{H}\right\}$ NMR $(100 \mathrm{MHz})$ spectra of $42\left(\mathrm{CDCl}_{3}\right)$
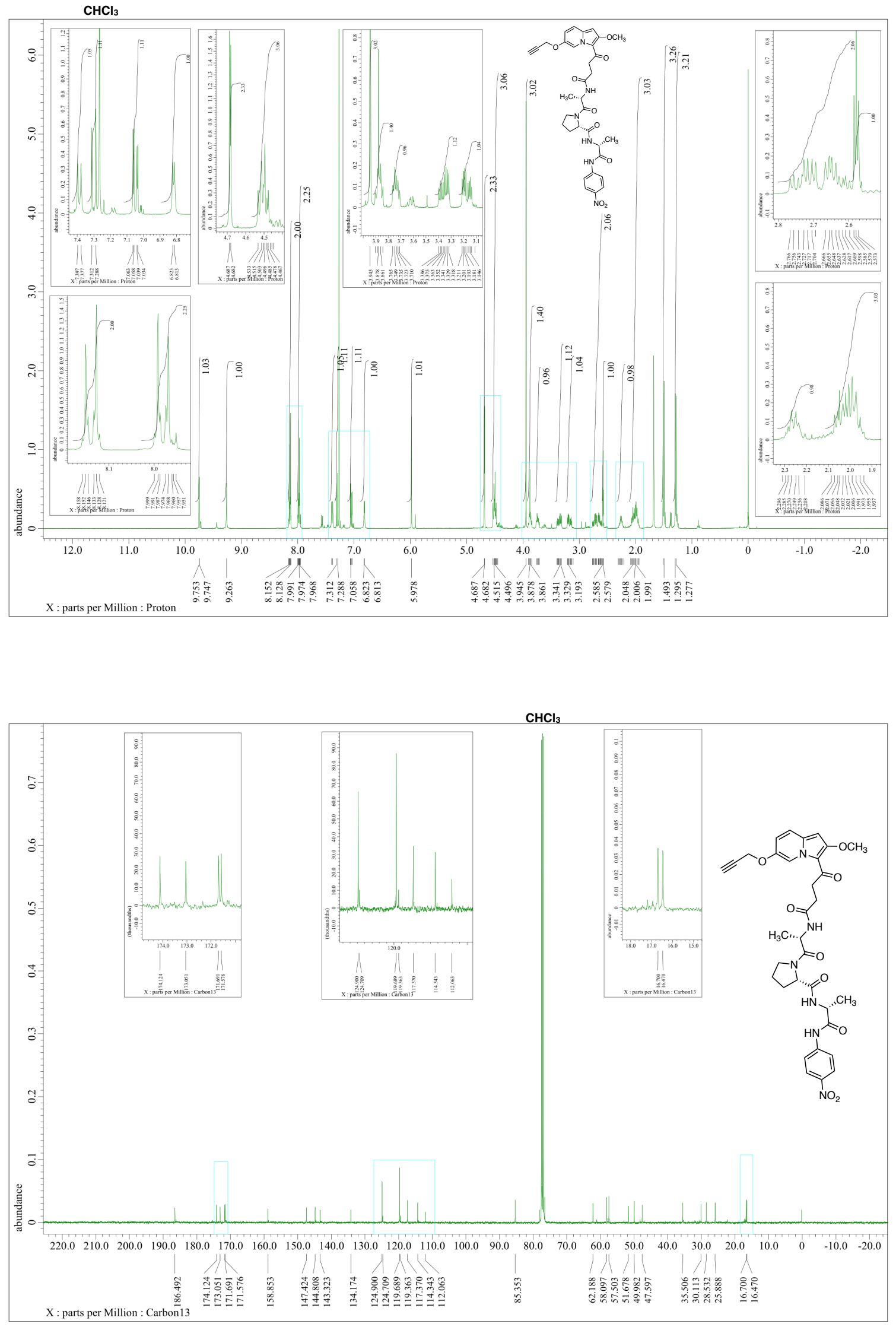
${ }^{1} \mathrm{H}$ NMR $(400 \mathrm{MHz})$ and ${ }^{13} \mathrm{C}\left\{{ }^{1} \mathrm{H}\right\}$ NMR $(100 \mathrm{MHz})$ spectra of $33\left(\mathrm{CDCl}_{3}\right)$
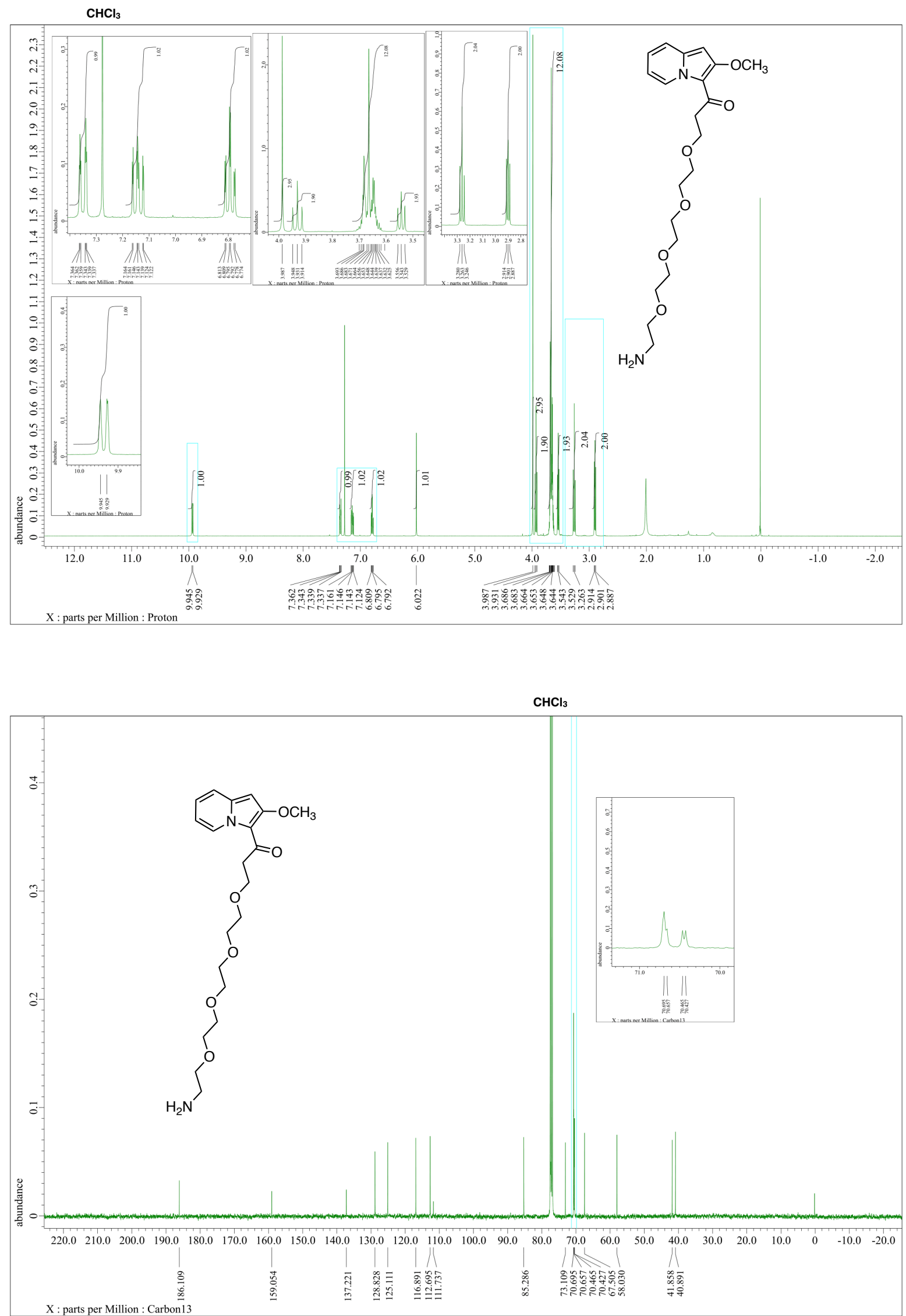
${ }^{1} \mathrm{H}$ NMR $(400 \mathrm{MHz})$ and ${ }^{13} \mathrm{C}\left\{{ }^{1} \mathrm{H}\right\}$ NMR $(100 \mathrm{MHz})$ spectra of diazido $46\left(\mathrm{CDCl}_{3}\right)$
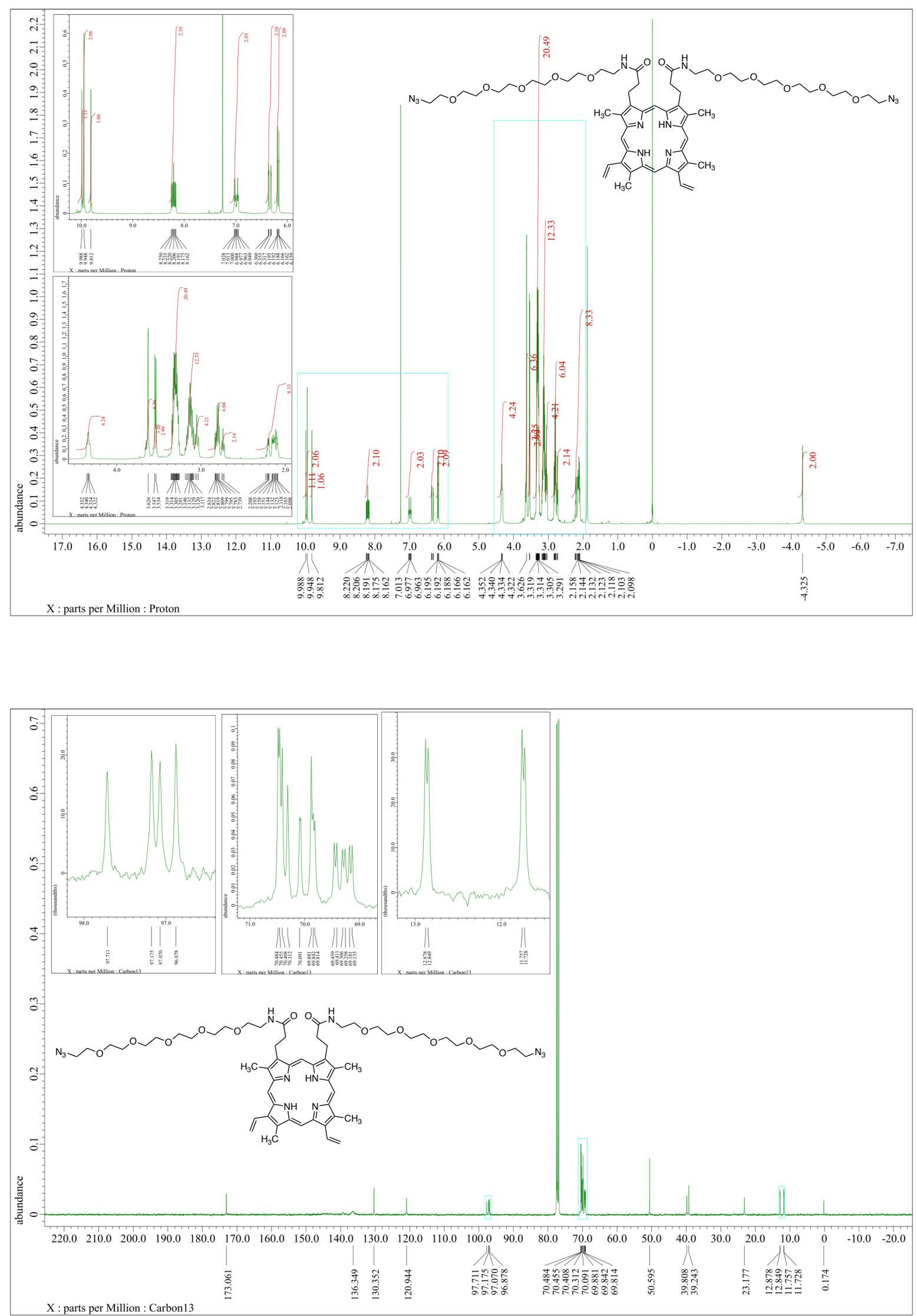
${ }^{1} \mathrm{H}$ NMR (400 MHz) and ${ }^{13} \mathrm{C}\left\{{ }^{1} \mathrm{H}\right\}$ NMR (100 MHz) spectra of diazido $43\left(\mathrm{CDCl}_{3}\right)$
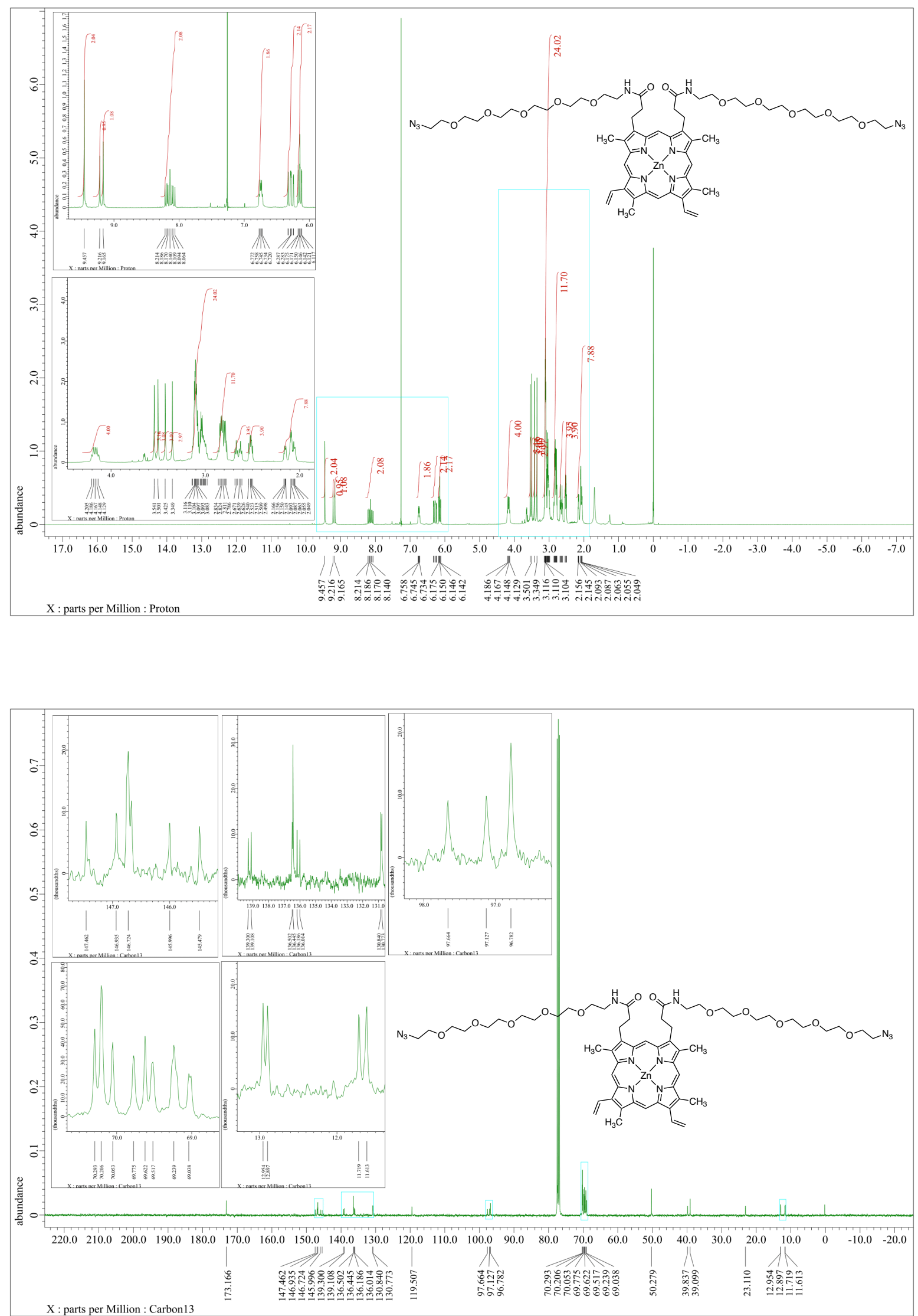
${ }^{1} \mathrm{H}$ NMR (400 MHz) spectrum $\left(\mathrm{CDCl}_{3}\right)$ and HPLC chart of $\mathbf{4 4}$

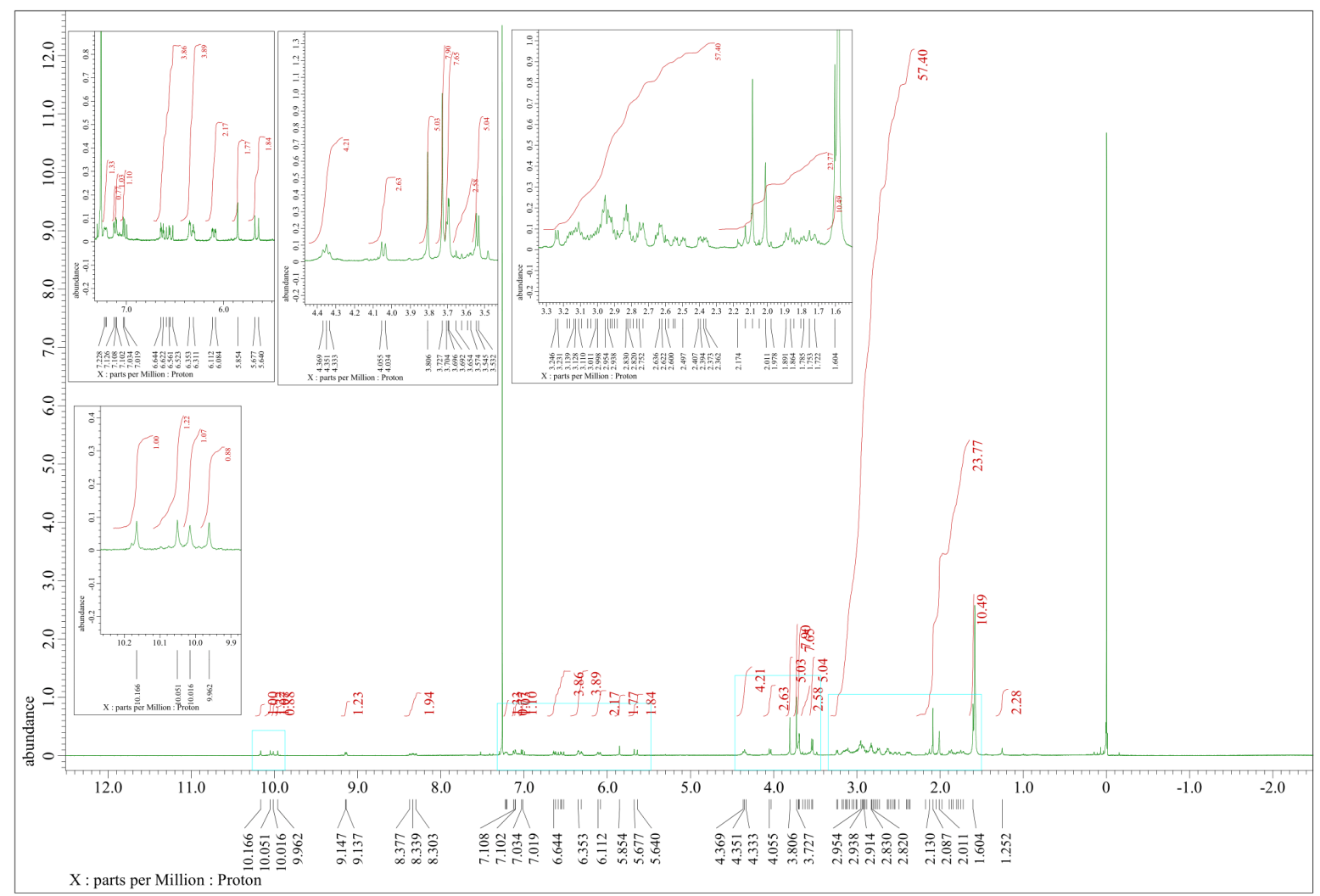

mAU

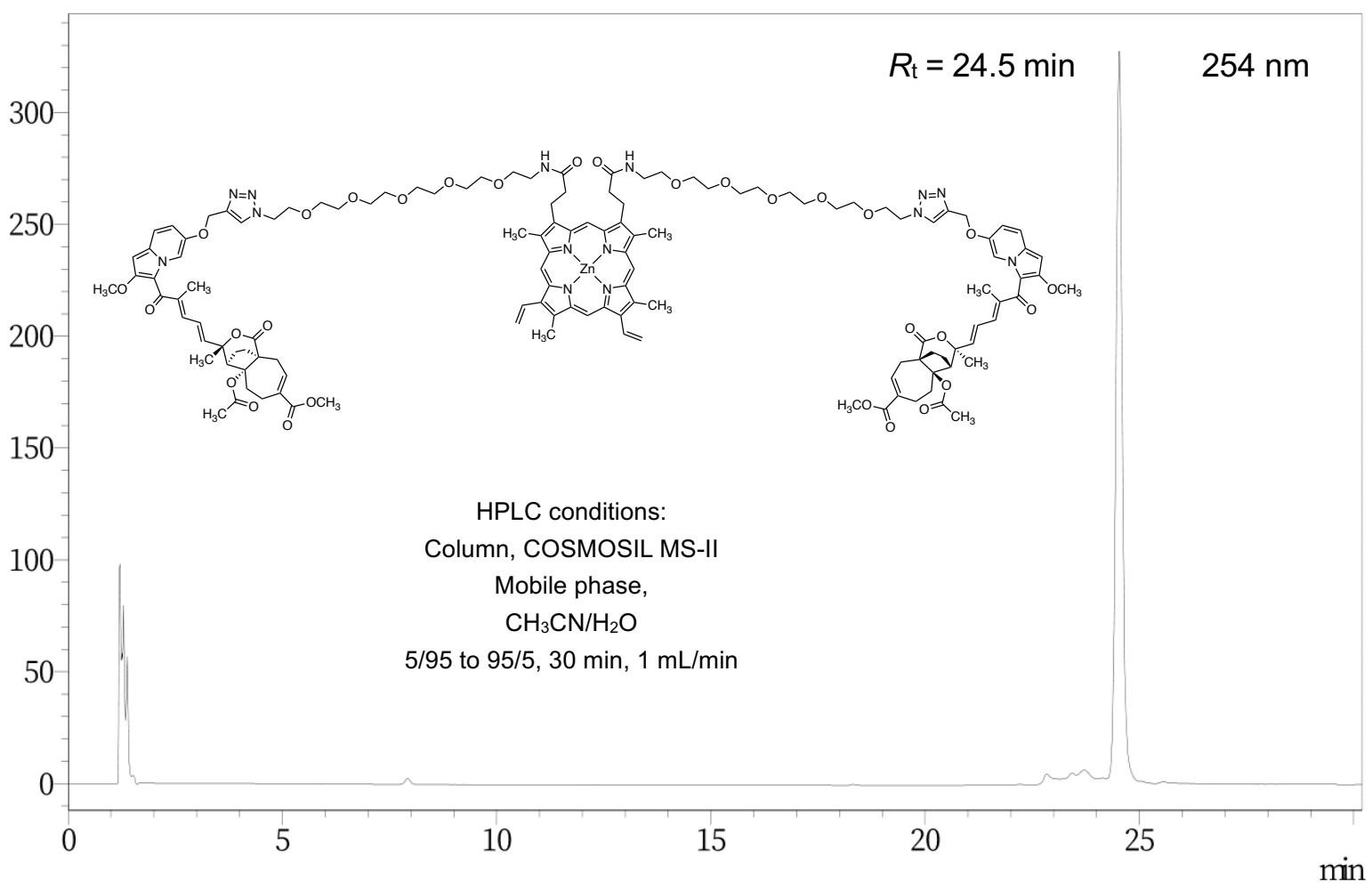


${ }^{1} \mathrm{H}$ NMR $(400 \mathrm{MHz})$ spectrum $\left(\mathrm{CDCl}_{3}\right)$ and HPLC chart of $45\left(\mathrm{CDCl}_{3}\right)$

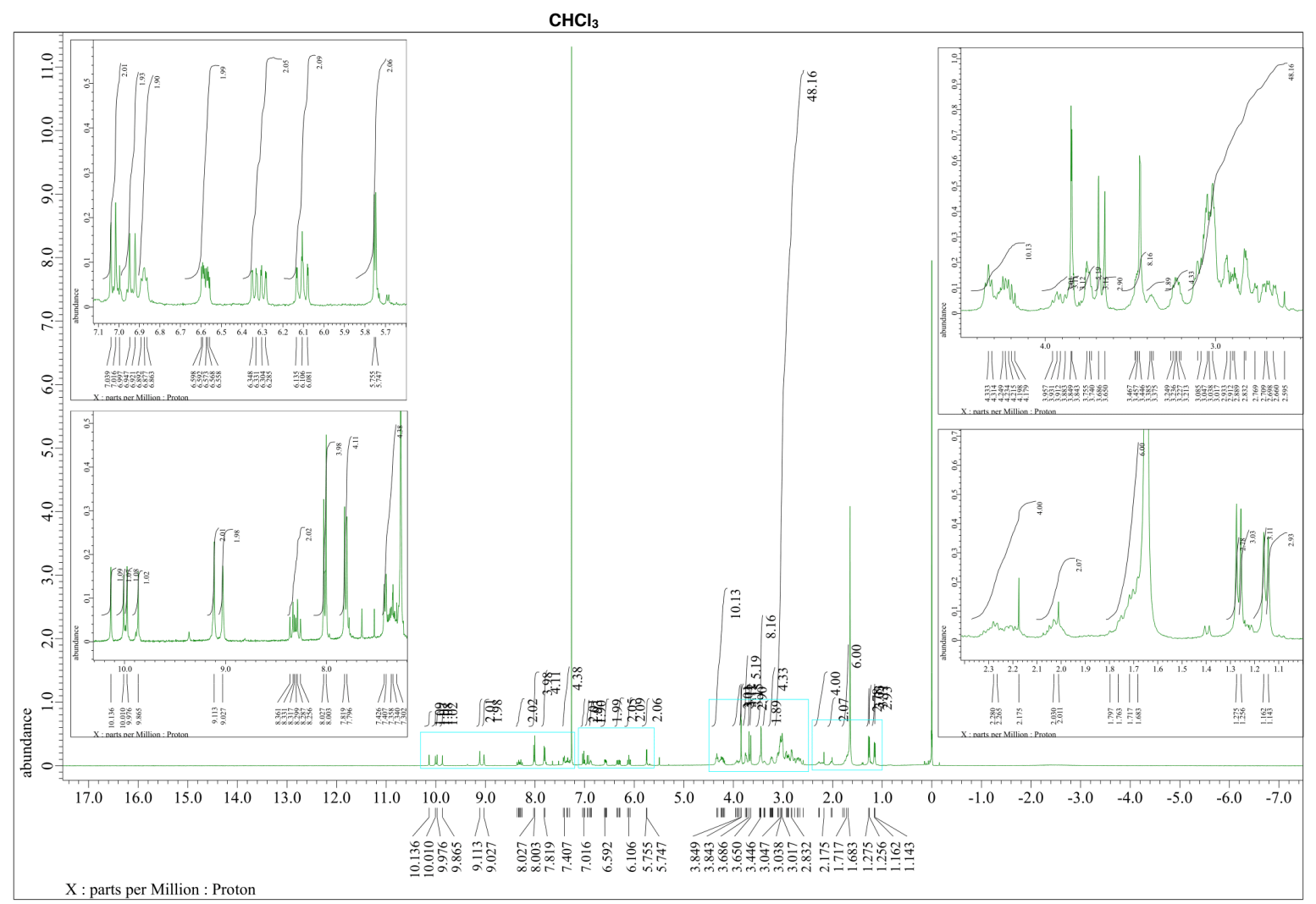

mAU

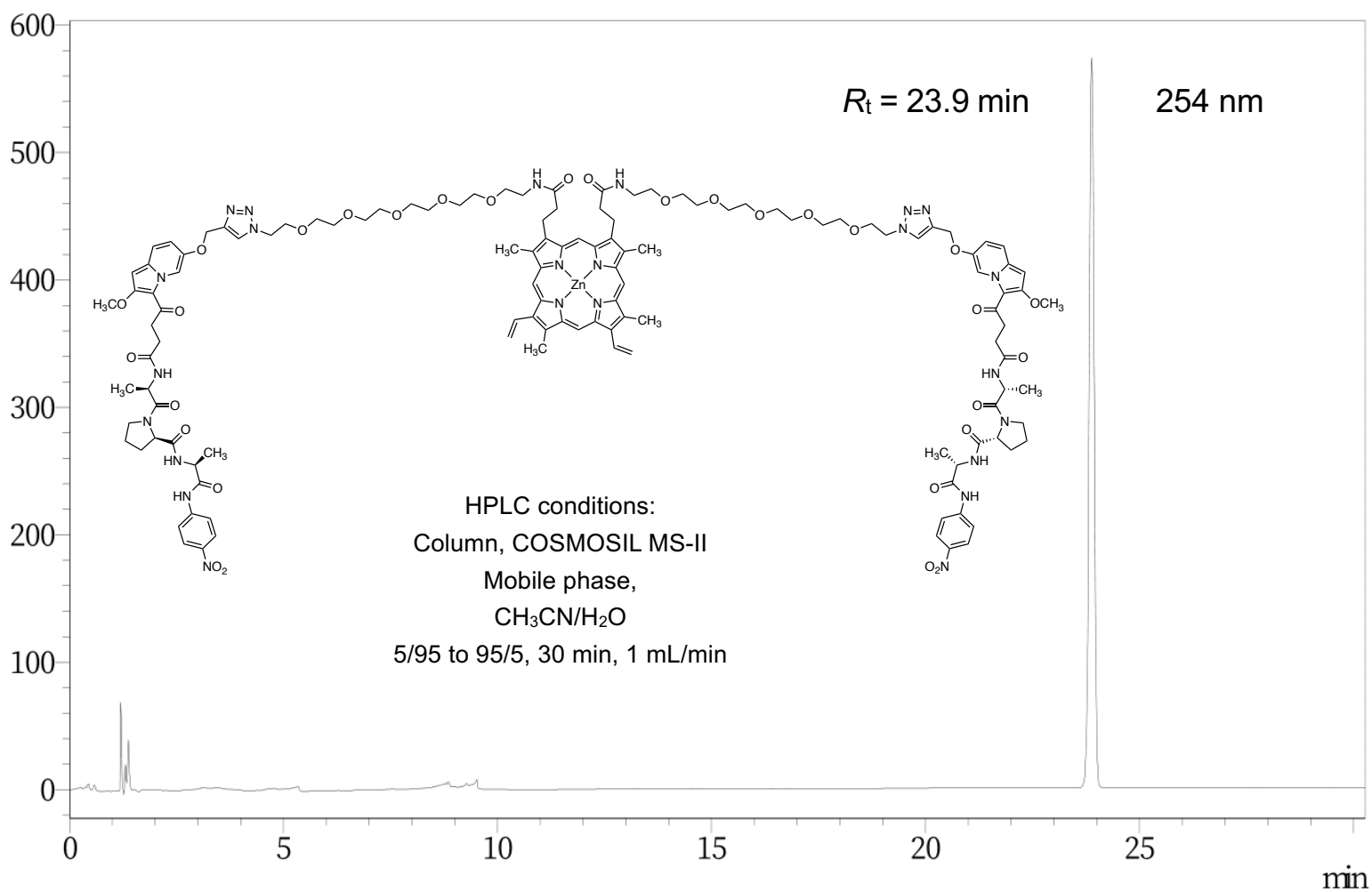


${ }^{1} \mathrm{H}$ NMR $(400 \mathrm{MHz})$ and ${ }^{13} \mathrm{C}\left\{{ }^{1} \mathrm{H}\right\}$ NMR $(100 \mathrm{MHz})$ spectra of $39\left(\mathrm{CDCl}_{3}\right)$
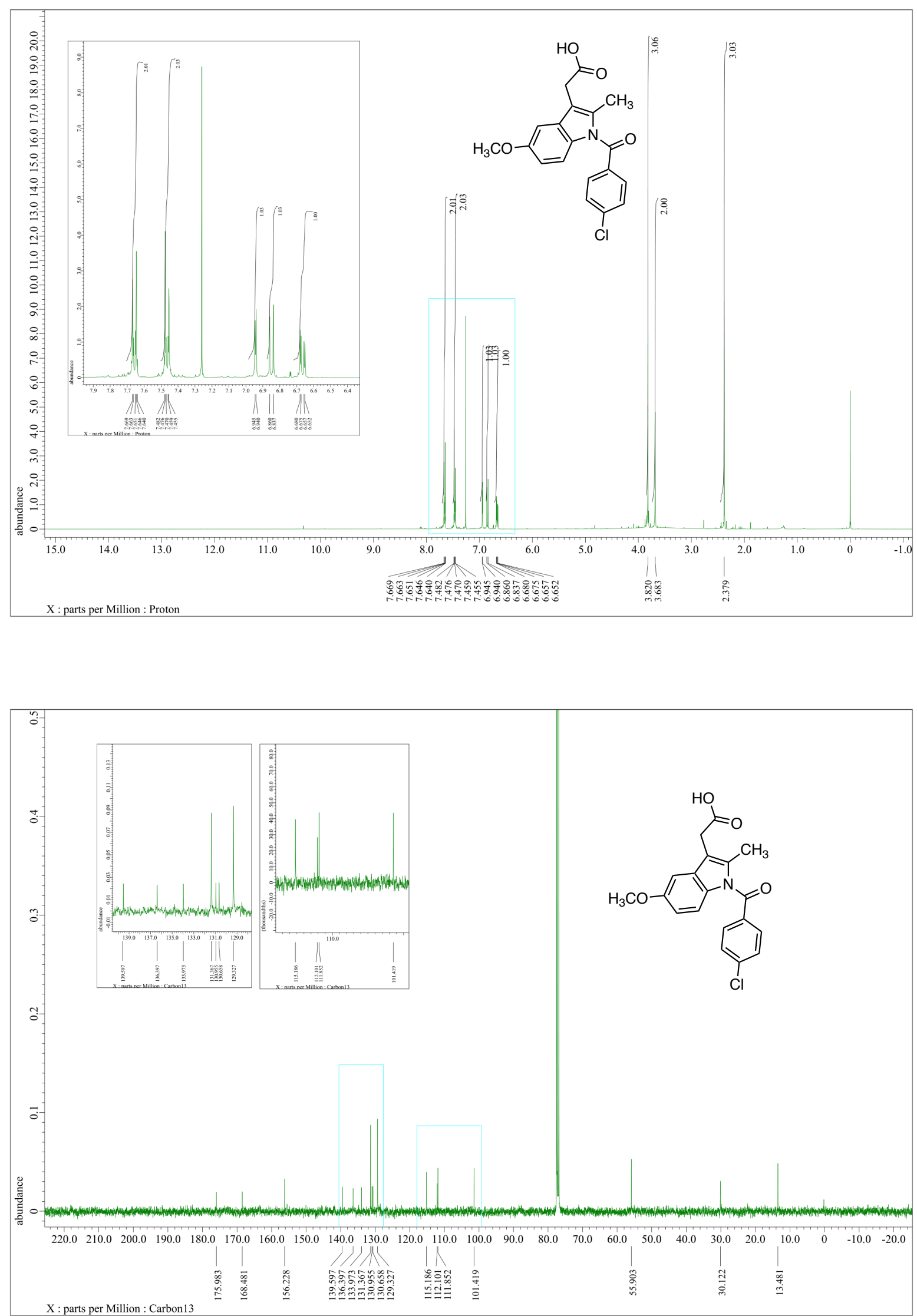


\section{Chiral HPLC charts}

Chiral HPLC charts of 22 and $r a c-22$ (column, IA; mobile phase, Hexane $/ i-\mathrm{PrOH}=9 / 1,1 \mathrm{~mL} / \mathrm{min}$ )

mAU

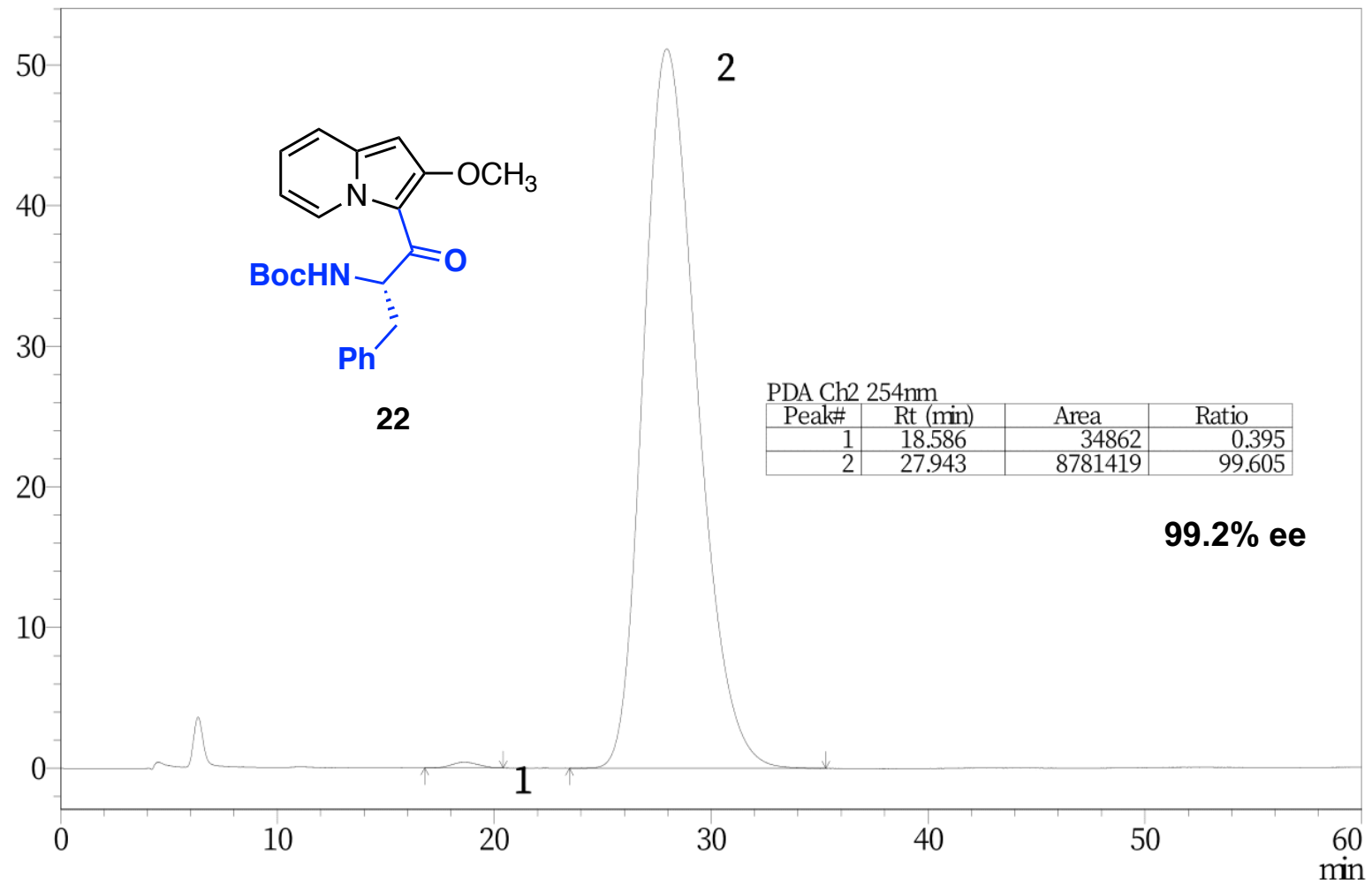

mAU

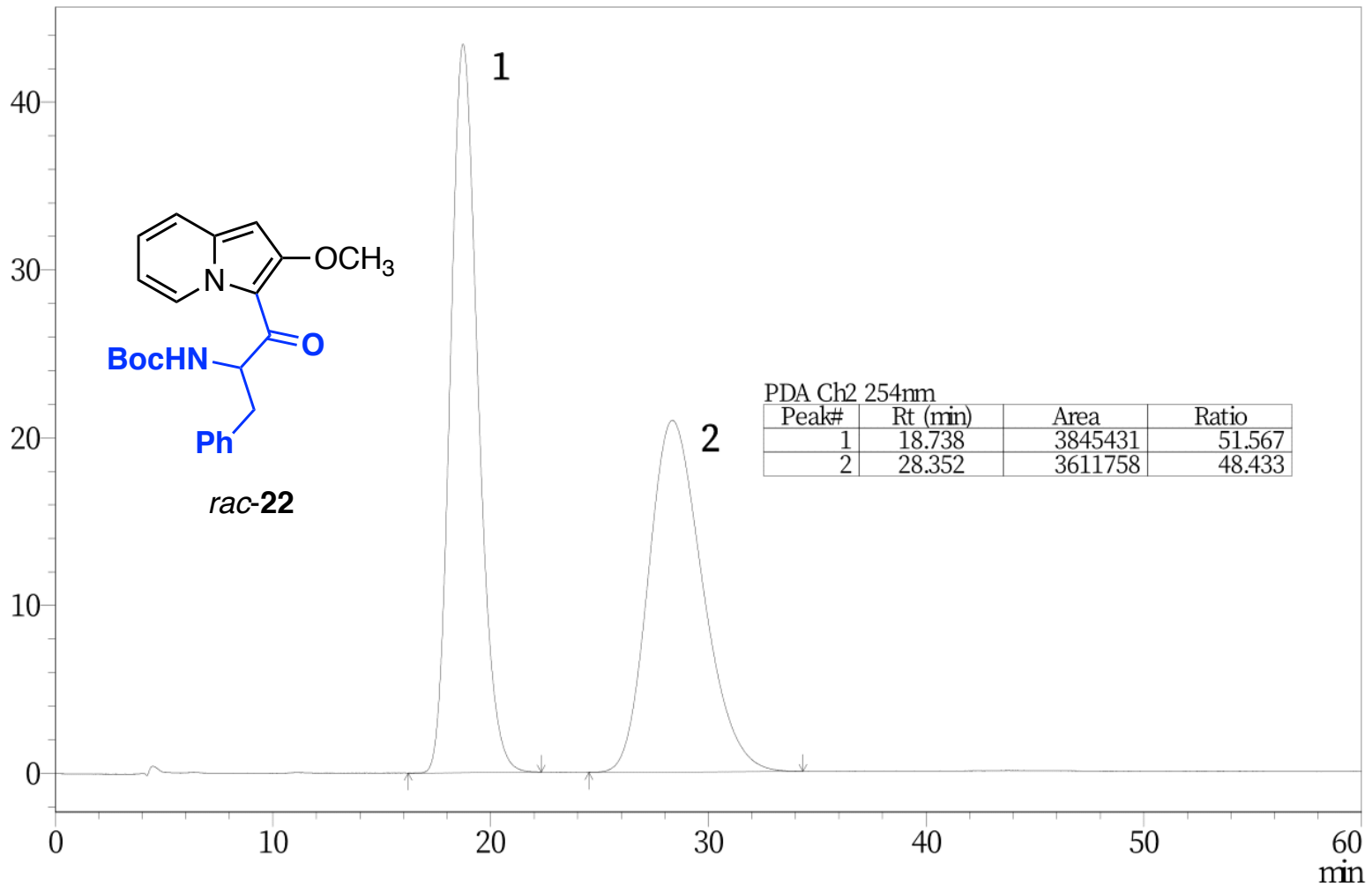


Chiral HPLC charts of (tert-butoxycarbonyl)-L-phenylalanine (released from 22) and its racemic standard (column, IA; mobile phase, $\mathrm{Hexane} / i-\mathrm{PrOH} / \mathrm{HCO}_{2} \mathrm{H}=900 / 99 / 1,1 \mathrm{~mL} / \mathrm{min}$ )

mAU

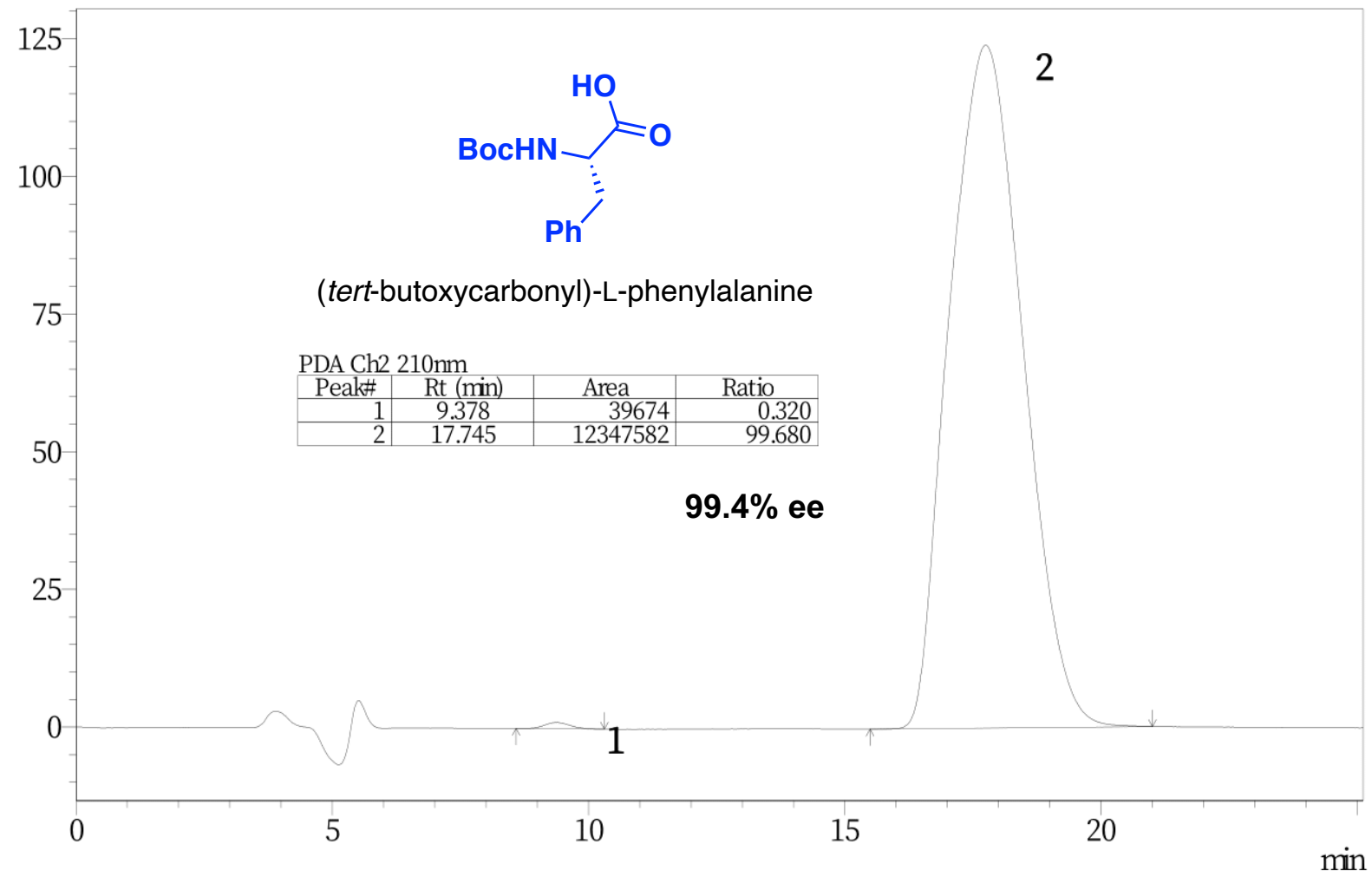

mAU

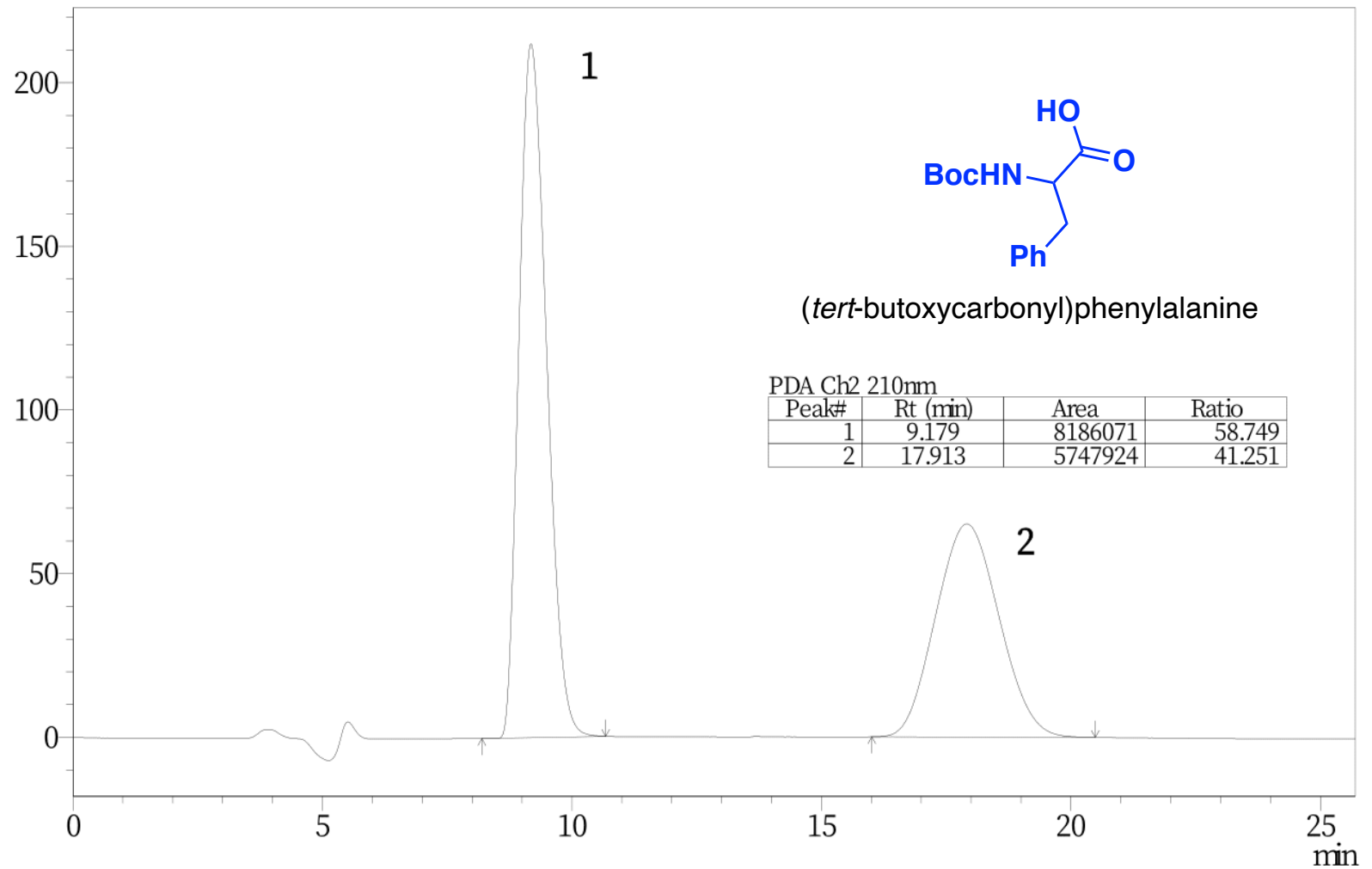

